\title{
La Vie
}

Monseigneur Saint Fiacre edited by

James F. Burks

Barbara M. Craig

M. E. Porter

UNIVERSITY OF KANSAS PUBLICATIONS

HUMANISTIC STUDIES NO. 33

LAWRENCE, KANSAS 


\section{The University of Kansas}

\section{COMMITTEE ON HUMANISTIC STUDIES}

\section{Clyde K. Hyder, Editor}

The University of Kansas Humanistic Studies are offered in exchange for similar publications by learned societies and by universities and other academic institutions. All inquiries and all matter sent in exchange should be addressed to the Library of the University of Kansas, Lawrence, Kansas.

\section{Volume I}

Number 1. Studies in the Work of Colley Cibber, by Dewitt C. Croissant. October, 1912. Seventy pages. Fifty cents.

Number 2. Studies in Bergson's Philosophy, by Arthur Mitchell. January, 1914. One hundred and fifteen pages. Seventy-five cents.

Number 3. Browning and Italian Art and Artists, by Pearl Hogrefe. May, 1914. Seventy-seven pages. Fifty cents.

Number 4. The Semantics of -mentum, -balum, and -culum, by Edmund D. Cressman. January, 1915. Fifty-six pages. Fifty cents.

\section{Volume II}

Number 1. Oriental Diction and Theme in English Verse, 17.70-1840, by Edna Osborne. May, 1916. One hundred and forty-one pages. Seventy-five cents.

Number 2. The Land Credit Problem, by George E. Putnam. December, 1916. One hundred and seven pages. Seventy-five cents.

Number 3. Indian Policy and Westward Expansion, by James C. Malin. November, 1921. One hundred and eight pages. One dollar.

Number 4. American Indian Verse: Characteristics of Style, by Nellie Barnes. December, 1921. Sixty-four pages. Seventy-five cents.

\section{Volume III}

Number 1. The Relation of Ralph Waldo Emerson to Public Affairs, by Raymer McQuiston. April, 1923. Sixty-four pages. Seventy-five cents.

Number 2. The United States, 1865-1917: An Interpretation, by James C. Malin. January, 1924. Sixty-four pages. Seventy-five cents.

Number 3. Home's Douglas, edited, with Introduction and Notes, by Hubert J. Tunney. November, 1924. One hundred pages. One dollar.

Number 4. State Gasoline Taxes, by Edmund P. Learned. March, 1925. Ninety-six pages. One dollar.

\section{Volume IV}

Number 1. The Negro Character in American Literature, by John Herbert Nelson. September, 1926. One hundred and forty-six pages. One dollar.

Numbers 2 and 3. The Early Opposition to Sir Robert Walpole, 1720-1727, by Charles Bechdolt Realey. April, 1931. Two hundred and ninety pages. Two dollars.

Number 4. The Liquor Question among the Indian Tribes of Kansas, 18041881, by Otto Frovin Frederikson. April, 1932. One hundred and three pages. One dollar. 
University $_{\text {of Kansas, Publications }}$

Humanistic Studies, No. 33

$$
\text { La Vie }
$$

Monseigneur Saint Fiacre 


\title{
La Vie
}

\section{Monseigneur Saint Fiacre}

A Play from Manuscript 1131 of the Bibliotheque Sainte-Geneviève, Paris

\author{
Edited by: \\ James F. Burks, University of Minnesota \\ Barbara M. Craig, University of Kansas \\ M. E. PORTER, Indiana University
}

THE UNIVERSITY OF KANSAS PUBLICATIONS

LAWRENCE, 1960 
(C) Copyright 1960 by the University of Kansas Press

L.C.C.C. Number 60-62643

PRINTED IN THE U.S.A.

BY THE UNIVERSITY OF KANSAS PRESS

LAWRENCE, KANSAS 


\section{Preface}

Manuscript 1131 (hereafter abbreviated as Gen 1131) of the Bibliothèque Sainte-Geneviève in Paris contains the sole surviving text of the following plays: La Nativité Nostre Seigneur, Le Geu des trois roys, La Resurrection Nostre Seigneur, La Vie Monseigneur Saint Fiacre, La Passion Nostre Seigneur, Le Martire Saint Estienne, La Conversion Saint Pol, La Conversion Saint Denis, Comment Saint Pere et Saint Pol allerent a Romme, Le Geu Saint Denis, Les Miracles Madame Sainte Geneviève. In addition, there is a prose life of Ste. Geneviève, with three French and four Latin prayers to her.

A poor transcription of the plays, almost without notes and in no sense a critical edition, was published in 1837 by Achille Jubinal under the title Mystères inédits du quinzième siècle in two volumes which are all but unavailable today. His text of the Fiacre play alone, aside from some eighty-three inconsistencies in spelling, contains many erroneous readings which often vitiate the meaning of the text. In his Théatre français avant la Renaissance, Edouard Fournier republished three of the plays (Conversion Saint Pol, Conversion Saint Denis, and the Vie de Saint Fiacre). This version is even less satisfactory than that of Jubinal. In the case of the Fiacre play, while following Jubinal's text, Fournier adds a number of errors of his own invention. In all there are 176 incorrect readings, together with many completely erroneous interpretive notes. ${ }^{1}$

Of the eleven plays, to date only four have been edited in accordance with the standards of modern scholarship. These are the Miracles Madame Sainte Geneviève (by Clotilde Sennewaldt, Frankfurt a. Main, 1937), the Nativite Nostre Seigneur and the Geu des trois roys (by Ruth Whittredge, Bryn Mawr, 1944), and the Resurrection Nostre Seigneur (by James F. Burks, unpublished Indiana University dissertation, 1957).

The collection of plays in Gen 1131 is significant for the early history of the French theatre because it represents a step in the transition from the earlier liturgical drama to the vernacular plays of the fifteenth century, and also because it was probably the repertory of one of the early

1. In addition to failure to correct obvious scribal errors (facent 862 , seront 1008 , vendrons 1025), Jubinal's text contains such misreadings as tot for tant 10; manie for maniere 25; devisiez for avisiez 55; gente for goute 114; l'erme for le terme 204; Feutse l'omme for Fent sel omme 377. 
dramatic confréries in Paris. Since not all of the plays are by the same author or date from the same period, it is most desirable that each be edited and published so that an evaluation may be made of their relationship to one another and to the repertory of the time. It is, therefore, for the partial fulfillment of such a purpose that the present edition of the Vie Monseigneur Saint Fiacre (hereafter abbreviated as VSF) is being offered; it is hoped that the other plays in the manuscript will eventually receive adequate treatment.

Of the Gen 1131 plays, the VSF, a relatively well-constructed presentation of a popular saint's legend, is particularly suited to separate publication, for it is the only saint's play in the collection not directly connected with the hagiography of the Paris region. It is additionally of interest because it, unlike any other dramatic production of its time, contains as an integral element a ribald farce which is perhaps the earliest example of a conventional French farce so labeled by the author.

The editors wish to express their gratitude to Professor J. Neale Carman, Chairman, Department of Romance Languages, University of Kansas, and to Dr. Clyde K. Hyder, Editor of the University of Kansas Press, for their invaluable comments and suggestions regarding many aspects of the edition. Any defects found in it, however, are the responsibility of the editors. 


\section{Contents}

AbBREVIATIONS ..................................................................................................... viii

INTRODUCTION

I. The Manuscript ............................................................................... 1

II. The Legend and its Sources ........................................................... 2

III. The Farce ....................................................................................... 3

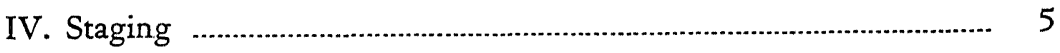

V. Connection with the Confréries ....................................................... 8

VI. Author, Language, and Date ..................................................... 10

VII. Versification ................................................................................... 13

VIII. Procedure Followed in Editing ................................................... 14

La Vie Monseigneur Saint Fiacre ................................................................ 17

Appendix: Historical Notes _...................................................................... 39

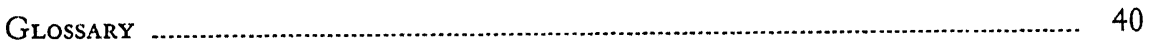

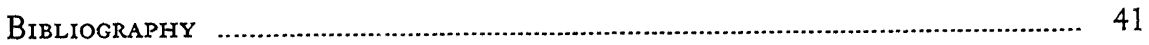




\section{ABBREVIATIONS USED IN THE INTRODUC- TION, TEXT, AND NOTES}

CFMA-Classiques françats du moyen âge

éd., ed.-edition, editor

fem.--feminine

Gen 1131-Manuscript 1131 of the Bibliothèque Sainte-Geneviève, Paris

1., 11.-line, lines

mas.-masculinc

nom.-nominative

r.--rubric

ro - recto

$R$-Romania

rev.-revised, revu(e)

$S A T F$-Société des Anciens Textes Français

SHF-Société de l'Histoire de France

sing.-singular

transl.-translator, translated by

vo_verso

voc.-vocative

VSF-La Vie Monseigneur Saint Fiacre 


\section{Introduction}

\section{The Manuscript}

Gen 1131 is a small paper volume in an easily legible semi-cursive hand of the fifteenth century. ${ }^{1}$ A red sign sets off each rubric and speech. The titles of the items contained in the manuscript, and the first letter of each verse, are either in red or have been painted over in that color. Pages and portions of pages left blank by the scribe bear remarks, scribblings, and drawings which were obviously added by later hands. ${ }^{2}$

On the last folio left blank by the scribe $\left(218^{\mathrm{ro}}\right)$, there is a statement by one Arnoul l'docte acknowledging that he had, on July 12, 1502, borrowed the volume from his uncle "Jehan l'docte, relligieux de l'abbaye et couvent de Saincte Genneviefve de Paris." Both Whittredge (p. 13) and Burks (p. 6) identify this Jehan l'docte as the monk who, according to manuscripts 1298 and 1872 of the Ste.-Geneviève library, was vested in 1472 . He is also mentioned in two other manuscript volumes of the library ${ }^{3}$ as being, in 1480, prior at Marizy, today known as Marizy-Ste.-Geneviève, canton of Neuilly-St.-Front, not far from Meaux. The fact that Marizy was during the Middle Ages a dependency of the Ste.-Geneviève establishment in Paris, accounts for Arnoul's description of his uncle as a "relligieux... de Saincte Geneviefve de Paris."

In his statement on $\mathrm{f}^{\circ} 218^{\mathrm{ro}}$, Arnoul further says that he is a resident of the village of "Coupeureez," a name difficult of interpretation, since he makes no distinction between $n$ and $u$. Some critics have thought that he meant Compiègne, but, as is pointed out by Miss Whittredge (p. 12, n. 9), this identification is probably incorrect, since Compiègne is spelled in the modern manner in line 1980 of the Nativité, and, since it was an important fortified place, Arnoul would not have called it a village. Burks (p. 6), after examination of published and unpublished sources, concluded that Arnoul's "Coupeureez" is probably the present

1. Only short references to works cited are given in the notes of this edition. Full bibliographical details are readily obtainable from the bibliography at the end of the volume.

2. For more detailed descriptions of the manuscript, see Kohler, I, 511-13; Whittredge, pp. 9-15; Sennewaldt, pp. 1 ff.; Burks, pp. 6 f.; Petit de Julleville, Mystères, II, 380-82. Some of the sketches and scribblings are reproduced on the flyleaf of each of the volumes of Jubinal's Mystères inédits.

3. DuMolinet, Histoire de Sainte Geneviève and his Inventaire des principaux manuscrits. 
hamlet of Coupvray, canton and commune of Lagny, near Meaux and Marizy-Ste.-Geneviève. If such is the case, it is possible that the manuscript was at Marizy when it was borrowed by Arnoul in 1502. Also, the fact that the Fiacre play was included in the manuscript, and that prominent roles are given to other saints (Geneviève, Denis, Sentin, Antonin, Céline) closely associated with the hagiography of the diocese of Meaux, lends credence to the additional possibility that it was actually compiled and/or copied at Marizy, where all these saints were undoubtedly known and revered. ${ }^{4}$ In any case, no known fact concerning the manuscript or its history forces a different conclusion, though an alternative possibility would be that Fiacre was known at Ste.-Geneviève in Paris because of the proximity of the dependency to his home country.

Gen 1131 is one of the few volumes now in the Bibliothèque Ste.Geneviève known to have been there during the Middle Ages. It was out of the library for a time during the sixteenth and seventeenth centuries, but it had made its way back before DuMolinet made his inventory in 1687. In 1760, it was lent to the Duc de la Vallière ${ }^{6}$ and was returned shortly after his death in 1780 . After that, with the exception of a short period when it was in the possession of Achille Jubinal during the 1830 's, it has remained in the library.

\section{The Legend And Its Sources}

The great popularity of the Fiacre legend during the later Middle Ages is attested by the ten French works devoted to it during that period. ${ }^{1}$ Fiacre, supposedly of royal blood and originally named Fefrus, was one of the many Irish monks who emigrated to the Continent during the seventh century. He settled as a hermit at Brogilium (Breuil, now the hamlet of St.-Fiacre) near Meaux, where he is said to have died in 670. His relics and his stone (referred to in lines $412 \mathrm{ff}$. of the VSF) are still displayed in the church there. Fiacre, patron saint of Brie as well as of gardeners in general, is also regarded as the healer of the fic

4. For discussion of other aspects of this matter, see below, p. 9.

5. See Whittredge, p. 13.

6. He published a summary of the play in his Bibliothèque du théatre françois depuis son origine (Dresden, 1768).

1. For these and the legend in general, see Porter and Baltzell, pp. 21-27; Lecotté, p. 357 and passim. 
(from Latin ficus, "fig," "fig-shaped excrescence," "hemorrhoids"), which may account for the change of his name from Fefrus to Fiacre.

A Latin life of Fiacre is published by the Bollandists in Acta Sanctorum, VI Aug., 598 ff. (Palmé edition, Paris/Rome, 1868). Other Latin accounts are listed by Hardy in his Descriptive Catalogue, Vol. I, pt. 1, pp. 272-74, and in the Bollandists' Bibliotheca Hagiographica Latina, I, $439 \mathrm{f}$. No one of these is, however, identifiable as the direct source of the VSF, which merely follows, with slight differences of detail, the main lines of a well-known legend that had appeared in the Vignay translation of Voragine's Legenda Aurea. ${ }^{3}$

\section{The Farce}

The VSF is unique among religious French plays of its time in that it contains a complete farce inserted ${ }^{1}$ between the death of the Saint and the miracles performed at his shrine. The verse structure, including the four-syllable cue-line, and the language, both exactly like the same features in the remainder of the play, indicate that it was an integral part of the VSF as a whole and that, if it was not composed by the author himself, it was added by a redactor who worked at approximately the same time.

The subject matter of the farce, which has no connection with the story of the Saint, pictures realistically the everyday life of the lower classes. It is divided into two parts. In the first (710-849), a Brigant meets a Vilain, steals from him a fat capon, is challenged by a Sergent de police, defeats the latter, and escapes with his prize. In the second half (850-989), the wives of the Vilain and Sergent indulge in strong drink at a tavern and are on that account beaten by their husbands.

The farce, with its thin plot, elementary characterizations, and reliance on fisticuffs and vulgar language for its humor, has no great intrinsic value. ${ }^{2}$ It is hardly more than a loosely constructed skeleton

2. See Kraemer, pp. 23 ff.

3. See Butler, passim; Knowles, pp. 353 ff. The Legenda aurea as edited by Graesse does not contain the life of Fiacre.

1. The word farsse is used here substantially in its etymological sense, that of "something inserted into something else."

2. Harvey, p. 113, has a higher opinion of it. He says: "The author is an excellent dramatic artist, and his point of view is that of an intelligent person of good social class." 


\section{LA VIE MONSEIGNEUR SAINT FIACRE}

instance do the rubrics reveal any concern on the part of the dramatist for the methods to be followed in the staging of his play.

In spite of the limited information provided by the playwright, certain elements of the text of the VSF, and also what we know of the staging of medieval plays in general, enable us to form some idea of the mise en scène. ${ }^{3}$ It is almost certain that the play was planned to be performed indoors with the simultaneous setting customary in the medieval period. ${ }^{4}$ The stage must have had two levels, the one representing Heaven and the other, earth. Across the back of the "earthly" level could be fixed mansions or lieux representing the clearly defined locations of action. The full width of the front of the stage, usually referred to as the champ, would be the acting area on which the less clearly localized events, and also the numerous journeys that are included in this play, would be represented.

Four mansions of some complexity would be required for a performance of the VSF. The first is, of course, Heaven, shown probably as a balcony or platform situated above the main champ, but connected to it by steps or a ladder. ${ }^{5}$ A second important property is the little ship that transports Fiacre, and later his would-be fiancée, from Ireland to France (244-55 and 475-81). The third required lieu is a hut to represent Fiacre's hermitage. The text of the play indicates that this structure was sufficiently large to permit two adults to stand inside it and carry on a conversation. ${ }^{6}$ The last fixed location is the tavern which served as a setting for the second part of the farce (894-989). It is doubtful that more than a suggestion of such a building appeared on the stage. The lieu privé, where the two wives go to enjoy their drinks ( 895 and 899 ), could readily be implied by the use of tables and screens or simulated hedges.

3. For discussions of the staging of medieval French drama, see G. Frank, pp. 69-73, $83-84,90-91,104,111,128-29,148-50,163-69$, and 269-70; Cohen, Histoire de la mise en scène and Livre de conduite . . ; D. Penn; Whittredge, pp. 63-78.

4. There is no indication within the VSF that the play was destined for indoor presentation. In view of its probable connection with a Paris confrérie, however, we can presume that the play was intended for performance in a hall comparable to that of the Hopital de la Trinité, where the Confrérie de la Passion staged its plays.

5. For a discussion of the probable manner of staging Heaven in the Miracles de Nostre Dame, see Penn, pp. 15-16. The same kind of setting would be suitable for the VSF.

6. In 1. 535, the Pucelle, standing outside the hermitage, says "J'enterray ens," and the conversation that follows must have taken place within the hut. 


\section{INTRODUCTION}

Additional stations of less importance may have been prepared to represent the church of St. Pharon (326 and 336), the bench on which the latter rests as he travels from Fiacre's hermitage back to Meaux (338-43), and the altar on which are placed the relics of the Saint (1019-22). It is possible that lieux of some sort were provided to represent the family home of Fiacre and that of the Pucelle. As there are no indications, however, that such properties appeared on the stage, it is also possible that the scenes involving these characters took place on the champ. Here, too, would be shown the meeting of the Brigant and the Vilain, their subsequent fight, and the conversation of the wives before their visit to the tavern. The edges of the champ must have served as the starting place of the various invalids who seek the aid of the Saint in the last section of the play (1082, 1120, 1136, 1198, and 1234).

Considerable ingenuity on the part of the producer would be required to do justice to the Heavenly Conclave and to the appearance of the Archangels before Fiacre and Pharon. Equally difficult to stage would seem to be the miracle wrought by Fiacre when he began to prepare his hermitage, and the journeys by land and water. Although our playwright does not tell us how these scenes were to be brought to the stage, we can point to other plays where similar problems of staging were encountered and overcome. In the fourteenth century Miracles de Nostre Dame of the Cangé manuscript, contacts between the Heavenly Host and characters of the plays were regularly represented. ${ }^{7}$ Similarly, there are several early examples of the presence on the stage of simulated bodies of water over which mechanically motivated boats could pass. ${ }^{8}$ The miraculous moving of quantities of earth by a few thrusts of the spade in our play (344-57) would be no more difficult to present than the "Miracle of the Sower" in the Geu des trois roys in Gen $1131 .{ }^{9}$ Stage directions of the Geu des trois roys (378 r. and $388 \mathrm{r}$.) show that journeys were suggested in that play by having the travelers make sev-

7. The appearance of the Virgin, usually accompanied by God the Son and a group of angels, was an important feature of nearly all of the Miracles de Nostre Dame.

8. In the Royal Palace at Paris, in 1378 and 1379, there was presented a dramatization of the First Crusade which included the use of a ship that could be moved on wheels. For the best and most recent discussion of this spectacle, see Loomis, pp. 242-55. Boats also appeared in several of the later Miracles de Nostre Dame, namely numbers XXVII, XXIX, XXXII, XXXIV, XXXVII, and XL. For a study of the staging of this element in the miracle plays, see Penn, pp. 39-41.

9. See Whittredge, Geu des trois roys, lines 1013-36, 1069-77, 1286-1305, and 1370-85. 


\section{LA VIE MONSEIGNEUR SAINT FIACRE}

eral turns around the stage before reaching their destination. This same practice was undoubtedly followed in the VSF. Whether in our play the boat left its "sea" to move around the stage on wheels before "docking" at the "French port" is not stated, but this seems entirely possible.

Our playwright's silence as to details of staging leads one to believe that he was writing in a well-established tradition for a confrérie which was accustomed to produce religious plays and was therefore equipped with all the devices needed for a realistic performance. Our play actually offers few new problems of mise en scène. An experienced producer, who had perhaps seen some of the Miracles de Nostre Dame and helped with earlier plays of the Gen 1131 manuscript, would have had little trouble in bringing the VSF to the stage.

\section{ConNeCtion With the Confréries}

Most critics $^{1}$ who have studied the Gen 1131 collection have concluded that it represents the repertory (or a part of it) of the Confrérie de la Passion, the earliest permanent theatrical company in Paris. These critics base their opinion on several considerations. The plays as a group conform to the definition "quelque misterre que ce soit, soit de ladicte Passion et Resurrection, ou autre quelconque tant de Saincts comme de Sainctes") contained in the famous letters patent ${ }^{2}$ by which Charles VI in 1402 permitted the Confrérie de la Passion to perform in public for profit. Gen 1131, in addition, gives every evidence of having been copied in or near Paris and the subject matter of the saints' plays, with the exception of the VSF, arises directly out of the hagiographic legends of the capital. Finally, the plays, judging from the sometimes elaborate instructions given at various places in the manuscript for staging them singly or in groups, were composed for performance by actors and not for silent reading. Emile Roy, ${ }^{3}$ further, attempts to link the plays with Paris by identifying several place names occurring in them with localities which existed in the French capital.

1. Lucien Foulet in Bédier and Hazard, I, 101; Creizenach, I, 253; Groeber, I, 212; Lanson, p. 204; Sennewaldt, pp. 5-7; Whittredge, pp. 27 ff.; Roy, Mystère de la Passion, I, 63-64; Roy, Etudes, pp. ccvi ff.; Frank, p. 147.

2. The text is given by Petit de Julleville, Mystères, I, 417-18.

3. For instance, the archidiacre in line 942 of the Miracles de Sainte Geneviève says: "Je voiz disner a Saint Fiacre." Roy (Etudes, p. ccv) identifies this with the cul-de-sac Saint Fiacre, which still opens into the Rue St. Martin. 


\section{INTRODUCTION}

Since so little is presently known, however, of the origins and early history of the Confrérie de la Passion, it is not possible to establish the fact that the Gen 1131 plays were performed by that group. Indeed, certain considerations lead to a belief that such may not have been the case. It is known that other companies were active in the presentation of plays in and around Paris in the late fourteenth and early fifteenth centuries. ${ }^{4}$ Burks has found that a confrérie dedicated to Ste. Geneviève herself was sanctioned by letters patent of Charles VI in $1412 .{ }^{5} \mathrm{He}$ suggests the possibility, therefore, that Gen 1131, a collection of plays centered around the Ste. Geneviève legends, was the repertory of this Confrérie de Ste. Geneviève associated with the Ste.-Geneviève monastery in Paris rather than that of the Confrérie de la Passion which was connected with the Église de la Trinité. It is certainly reasonable to believe that such an important church center as the Ste.-Geneviève monastery would have had its own organization and repertory for the performance of religious plays.

Although it is believed that several of the plays in Gen 1131 date from a period much earlier than that at which the letters patent were granted to the Confrérie de Ste.-Geneviève, there are also indications that at least some of the plays had been in frequent use over a considerable length of time prior to their inclusion in the manuscript. It seems possible, therefore, that our collection is a repertory gathered perhaps at the time when the Confrérie de Ste-Geneviève was formally recognized by Charles VI (1412), though it is also possible that the confrérie unofficially had been presenting these and/or other plays earlier than that.

The fact that the VSF was included in a collection to which it seems extraneous raises another point for speculation. In the absence of information, one may conjecture that it was added by a scribe who had lived or worked at Marizy-St.-Geneviève (see above, p. 2) where it would have been well known to him. He may then have decided that its inclusion in his collection would increase the popularity of his company's

4. See Thomas, 609-10; Cohen in R, XXXVIII (1909), 592; Petit de Julleville, Mystères, I, 414-15; Whittredge, 28-29.

5. Burks, pp. 13-14, who cites Guénot, p. 114; Abrégé de la vie de Sainte Geneviżve, p. 41; LeMasson, p. 27. DuMolinet, in his history of the Ste.-Geneviêve monastery, however, does not mention the confrérie. For another group, the Confrérie des Porteurs de la Chasse de Madame Saincte Geneviève, this one in the sixteenth century, see the anonymous Antiquitez et remarques, pp. 3-4. 
repertory in the region of the patron saint of Brie, and would consequently increase the possibilities for performances by the company there. Such a hypothesis, tenuous as it is, tends to explain why the VSF was made a part of an otherwise homogeneous group, though it must not be forgotten that Denis, Geneviève, Sentin, Antonin, Céline, saints associated with Meaux as well as with Paris, have important roles in several of the plays in the collection. ${ }^{6}$ All considerations, therefore, combine to make plausible the attribution of Gen 1131 not to the Confrérie de la Passion, but rather to a Confrérie de Ste.-Genevieve, associated with the Paris monastery and with Marizy-Ste.-Geneviève, which performed these plays both in the capital and in the territory under the patronage of St. Fiacre.

\section{Author, Language, and Date}

No information regarding the identity of the author of the VSF is available. His play shows, however, that he was a reasonably skillful versifier and that he had some dramatic talent. An examination of his language ${ }^{1}$ as reflected in rhyme and meter, indicates that he may have been a native of northeastern France, that he had probably become a resident of the Paris region, and that he wrote for audiences there toward the close of the fourteenth century.

Dialectal Traits. Several northeastern characteristics appear: 1) the reduction of -iée to -ie $(459,540,1030,1075,1129,1208$; but brisiee : prisiee $919-20$, which may be a scribal emendation; nee : brisiee 927-28) ; 2) weakness of $r$ in treuve : euvre 1037-38;3) rhyme of ai and oi (41-42) ; present subjunctive 4: paiomes 482;5) brache 928 (but bras 836, 846 , etc.); 6) the rhymes doumache : esrache 1221-22; vergongne: esloigne 147-48; fine : digne 1059-60. Though most of these localisms appeared early in the Francien dialect, ${ }^{2}$ they, few as they are, if taken in conjunction with the possible setting of the farce in Picardy, ${ }^{3}$ seem to point to a northeastern origin for our author.

6. On this, see Frank, pp. 139 and 147 , n. 1.

1. Poewe's dissertation on the language of the Gen 1131 plays is worthless, since it is based on Jubinal's text and since it assumes that all the plays are by the same author.

2. See Wacker, especially pp. 49 ff.

3. See Appendix, Historical Note to line 713. 


\section{INTRODUCTION}

Hiatus. The reduction of Old French hiatus resulting from the fall of an intervocalic consonant, while by no means complete, as the many instances of the diaeresis in our edited text show, has progressed further than it had in the Nativité, Trois roys, and Resurrection. ${ }^{4}$ It is maintained regularly in vëoir, meschëoir (meschëans 954, but meschans 1238), deüsses 29, eüsse 300, 776, 839; eüst 918; seüe 354; peüst 975; aparceüe 951; seür 407, 557, 665, 775; sceürement 562, 1058 (but asseuré 773); peür 408, 666, 776; bieneüré 1032; gaagnier 852 (but age 155). Apart from these cases, hiatus is not reflected in the meter of our play.

InfLectron. The Old French declension appears in only rare instances. At the rhyme, there is one assured instance of the mas. sing. nom. in -s (mis : amis 1019-20), and six in adjectives and participles (9, $447,690,734,954,1065)$. Against these there are at least five non-inflections in nouns $(24,520,535,860,970)$, and fourteen in adjectives and participles $(105,267,407,455,619,625,771,840,851,891,933,946$, 967, 1209).

Away from the rhyme, the only true cases of the Old French mas. sing. attested to by meter are four occurrences of homs for nom. and/or voc. sing. (407, 568, 732, 754) against five of homme (278, 334, 377, 454, 556). In the voc., sire predominates, though seigneur occurs.

The etymological fem. sing. form grant is usual (grans in fem. pl. 1134,1148 ), but grande at rhyme 1232 . Tel for fem. sing. occurs in 36 , $107,346,862,1038$ and the fem. pl. tielz 272, against tellez 274. Brief 763, loyal 1242, and quel 84 are fem.

Possessives. The etymological fem. sing. form moie has given way to the analogical $m a$ and mienne. Nostre and vostre are the only forms of these possessives used with singular nouns.

Verbs. Present Indicative. The first person singular of the first conjugation does not appear at the rhyme without analogical -e. Inside the verse, the only forms which do not have $-e$ are seven instances of pry (but prie 106); aing 431; doubt 596, dout 789, 885 (but doubte 823 and redoubte 888 , both at rhyme).

The ending -on never has $-s$ at rhyme $(608,694,804,855)$. The writing -ons, however, appears often inside the verse and may be scribal.

4. Whittredge, p. 84; Burks, pp. 84-87. 


\section{LA VIE MONSEIGNEUR SAINT FIACRE}

The sole example of the first person singular of conjugations other than the first at the rhyme is souvent : couvent $667-68$, without analogi$\mathrm{cal}-\mathrm{s}$. Inside the verse, promet 1188, repent 1193, requier 1203 appear, but it is impossible to determine whether these are due to the author or to the scribe.

Verbs. Present Subjunctive. The third person singular of the first conjugation always appears with analogical -e except gart 174, 240, 284, 547, 931 (but garde 4); port 611 (but porte 191); ottroit 71, 122, 1246; doint 272, 285, 289, 348, 1094. Gart, ottroit, and doint probably do not present the modern forms because they are survivals of old clichés.

In other conjugations, only puist 204, 330, 765, etc. (but puisse 57), has the old form, and here again the reason for it may be the survival of stereotyped expressions.

The present subjunctive 1 of aler is voise 257, 500; aille 769 at rhyme. The second person singular is voisez 606 and the third is voit 463, 849, 998, 1239; and in the plural, voison 617. Of estre, the subjunctive is always soie $(487,648,885$, etc.); of dire, only die 767 , desdie 433 , and diez 484 appear in the text.

Verbs. Imperfect and Conditional. The imperfect and conditional endings never present the analogical $-s$ in the first person singular (99, $109,440,651$, etc.).

Conclusion. While, as has been seen, the VSF maintains some linguistic archaisms, several features appear which indicate that the language belongs to a period later than that of the Nativité, Trois roys, and Resurrection. ${ }^{5}$ The declension in both nouns and adjectives has largely disappeared. The old forms of the possessive adjectives are completely absent. In verbs, there is a relatively high incidence of analogical $-e$ in present indicative 1 and present subjunctive 3 of the first conjugation. These phenomena, generally characteristic of the late fourteenth

5. The language of the Nativité, Trois roys, and Resurrection, as described by Whittredge (pp. 82-88) and Burks (pp. 82-97), is similar enough to indicate that the three plays may have been composed by the same author. In any case, they belong to an earlier period than does the VSF. In them, hiatus resulting from the fall of a consonant is generally retained. The Old French masculine declension, though not completely intact, appears much more frequently than not, and the etymological feminines of grant, tel, quel greatly outnumber the Middle French analogical feminine forms. In verbs, there is relatively little use of analogical $-e$ or $-s$ in the present indicative, and in the present subjunctive the older etymological forms predominate. The inflected possessives mes, sy, the short forms nos and vos, and the feminine moie are still found. 


\section{INTRODUCTION}

century, do not contradict the attribution ${ }^{6}$ of the VSF to that period. In any case, it was not composed by the same dramatist as the other three plays, though it may indeed have been reworked by the same redactor.

\section{VERSIFICATION}

The VSF is written in octosyllabic couplets. Each of the speeches ends with a four-syllable cue-line rhyming with the first line of the following speech, a technique which ocasionally appears in the Nativité, but not in the other plays in Gen 1131, and which serves both as a mnemonic device and as a means of varying the verse structure. Worthy of note is the fact that this is precisely the verse structure of the Miracles de Nostre Dame.

Examination of the rhymes indicates that lines are omitted before or after $25,114,521$, and that lines $737,962-63,1239$, as pointed out in the notes to the lines in question, were miscopied.

If account is taken of the fact that in plays intended for oral delivery, final mute $-e$ might or might not be counted as a syllable before a vowel, we find that there are few lines which do not have the proper number of syllables. These may easily be corrected by the addition of a common monosyllable, or by the substitution of a variant spelling of a word in the line. Only one imperfect verse, 989, a cue-line of five rather than four syllables, remains. Though these slight irregularities were not regarded as important in plays intended for performance, they have been corrected in this edition. Since there are so few octosyllables which cannot be restored by so simple a means as has been employed, it may be assumed that they were correct when they left the hands of the author.

That the poet was consciously interested in rhyme is indicated by the large number of rimes riches, rimes léonines, and rimes léonines riches which appear. There are fifteen instances of rime équivoque (7-8, $81-82,153-54$, etc.). There are only three rhymes of identical words

6. See Frank, p. 147; Wright, p. 50, n. 62; Sennewaldt, pp. 7-8, 55-56; Roy, Mystère de la Passion, I, 55-69, 116-18; Cohen, Théâtre religieux, p. 40. Lucien Foulet in Bédier and Hazard, I, 101-02, would date all the plays nearer the middle of the fourteenth century because of their similarities in form and structure to the Miracles de Nostre Dame. 
(111-12, 321-22, 807-08, the last of which, as is pointed out in the note to the line, may be a scribal error). There are two Latin-French rhymes (691-92, 693-94). The number of imperfect rhymes is small (347-48, 1053-54). There are numerous examples of enjambement $(8,12,28$, etc.).

\section{Procedure Followed in Editing}

The text has been transcribed as it appears in the manuscript, with all scribal inconsistencies in spelling such as the constant interchange of $-s$ and $-z$, an and $e n$, $a i$ and $e$, $s$ and $c$ before $e$ and $i$, etc. The few readings which have been rejected are given in the note to the line in question. Additions of common monosyllables to preserve meter are placed in square brackets. Abbreviations have been resolved in accordance, when possible, with spellings of the same word elsewhere. Changes of scene are indicated by a double asterisk before the first speaker or the first word of the new scene. Consonantal $i$ is transcribed as $j$ and mute $-e$ 's are printed in brackets when they count as a syllable, even when not written out in the manuscript.

Each of the editors was primarily responsible for certain aspects of the work. Dr. Burks contributed much of the new material concerning the history of the manuscript and its relation to the repertory of the confréries, as well as the study of the language and of the versification. Dr. Craig prepared the chapters on the farce and the staging of the play. Dr. Porter studied the legend and its sources, and established the text; he is also responsible for the notes and glossary. Each of the editors, however, had the assistance of the others in the preparation of his portion, and the collaborative effort was coördinated by Dr. Porter. 


\section{La Vie}

Monseigneur Saint Fiacre 


\section{CY COMMANCE LA VIE MONSEIGNEUR}

\section{SAINT FIACRE RIMÉE EN FRANCOYS}

LE PERE ST. FIACRE

$55 \mathrm{~d}$

Dame, mon pensser vous vueil dire;

Sachiez: $j[e]$ ay au cuer grant yre.

Toutes fois que mon filz regarde,

4 Je croy par Dieu, qui lez siens garde,

Que il ne vauldra ja riens nee.

Il est tout adez en pensee;

Il ne se porte bel ne gent;

8 Il samble que de bonne gent

Ne soit pas nez.

\section{LA MERE}

$56 a$

Monseigneur, tant de moy tenez:

Que sens sera s'en le marie,

12 Car lors maniere plus jolie

Demenra, creez ma parole.

Il a trop esté a l'escole;

Retraire le nous en convient.

16 D'estudier trop luy souvient:

Point ne m'agree.

\section{LE PERE}

Vous vous estes bien apenssee;

Ceste parole tieng a sage.

$20 \mathrm{Je}$ li veul dire mon courage.

$C y$ parle a son filz

Fiacre, mon filz, sa venez,

Ycy devant moy vous tenez, Sanz contredire.

ST. FIACRE

24 A vostre volenté, chier sire,
Feray de droit, je suis tenuz,

Car c'est droiture.

LE PERE

28 Mon chier enfant, de ta nature

Te deüsses porter jolis,

Et avoir gent corps et polis $56 \mathrm{~b}$

Et chevauchier et faire joye.

32 Il semble, quant tu vas la voie,

Que tu penssez trestout adez.

J'amasse miex qu'au jeu dez dez

$\mathrm{Ou}$ auls tables te deportasses

36 Qu'en tel guise te demenasses.

Ta guise mue!

ST. FIACRE

Mon chier seigneur, $j$ 'ay entendue

La parole de Jhesucrist;

40 Es Euvangiles est escript,

Dieu le dit, n'en suis en esmoy:

"Qui veult venir droit apres moy,

Renier li fault sa plaisance

44 Et prendre croix de penitance

Pour soy dez pechiez aquiter."

Et s'ay souvent oÿ conter

Qu'en doit pou prisier le solas

48 Dont en dit en la fin: "Helas!"

C'est verité.

LE PERE

Biau filz, j'ay de toy grant pitié.

Marier te fault, sanz doubtance,

52 Sy müeras ta contenance.

Cy parle au chevalier $56 c$

Entendez a moy, biau conpere,

26. The scribe seems to have omitted a line rhyming with tenuz.

30. The plural polis may refer to some word, like habits or vestements, understood, 


\section{LA VIE MONSEIGNEUR SAINT FIACRE}

Ou non de Dieu, nostre doulz pere,

Avisiez moy d'une pucelle

56 Qui soit sy avenant et belle Que a Fïacre puisse plaire Afin que le face retraire De la simple vie qu'il maine, 60 Qu'elle me semble trop vilaine Et dissolue.

\section{LE CHEVALIER}

J'en say une de grant value, Gente de corps et de visage,

64 Et sy est de noble lignage, Et de rente moult bien garnie. Elle sera moult esjoïe De Fiacre vostre filz prendre.

$$
\text { Cy s'en parte }
$$

68 Je la voiz querre sanz attendre. Je la voy la ou se repose. ${ }^{* *} C y$ parle a la pucelle Ma suer, Dieu, qui [de] tout dispose, Vous ottroit joye.

\section{LA PUCELLE}

72 Sire, Jhesucrist vous pourvoie! Dictes moy quel besoing vous maine;

Je ne vous viz mez dessemaine Prez de sa traire.

\section{LE CHEVALIER}

76 Vous le sarez sanz nul contraire. Monseigneur veult qu'a ly vegniez A celle fin que vous pregniez Fiacre son filz a mary.

80 Venez avec moy sanz destry, Et sy ly faites bonne chiere, A celle fin qu'il vous ait chiere. Miex en vauldrez.
LA PUCELLE

$84 G^{\prime}$ 'iray quel part que vous vouldrez,

Car j'ay en vous bonne fiance. Se le doulz Jhesus tant m'avance Que Fïacre me veulle prendre, 88 Guerredon vous en vouldray rendre

Bon et grant et a bonne chiere. Venez avec moy, chamberiere, C'est bon a faire.

LA CHAMBERIERE

92 Vostre volenté me doit plaire, Ma gracieuse damoiselle;

Bonne me samble la nouvelle Qu'avez oïe.

\section{LE CHEVALIER}

96 Alons ent, ne demourons mie,

Par ceste sente qui est plaine.

${ }^{* *}$ Cy parle le chevalier au pere St. Fiacre

Sire, cy endroit vous amaine

La damoiselle que disoie:

100 En couvenant la vous avoie, Vous le savez.

LE PERE ST. FIACRE

Biau compere, bien fait avez.

Cy parle a la pucelle

$\mathrm{Ma}$ fille, je vous ay mandee

104 Pour ce que bonne renommee Vous porte mon compere chier. Je vous prie que aprochier Veulliez de mon filz par tel guise 108 Que il vous ait a fame prise. Liez en seroie.

\section{LA PUCELLE}

A vostre gré faire m'ottroie. 


\section{LA VIE MONSEIGNEUR SAINT FIACRE}

A Fïacre vois sanz demeure;

$112 \mathrm{Ne}$ veul plus cy faire demeure.

A ly gentement parleray

Et biau samblant li monterray.

** Cy parle a St. Fiacre

(N'a soing, selon sa

contenance

$57 \mathrm{~b}$

116 .

Mon chier amy, sy suis venue-

A vous conforter sui tenue,

Car en m'en prie.

ST. FIACRE

120 En Dieu est mon confort, amie,

Car de solas mondain n'ay cure.

Dieu vous ottroit bonne aventure, Je le voudroie.

LA PUCELle

124 Mon chier amy, je loeroie

Que preïssiez esbatement,

Et que creez le loement

De vostre pere, qui est sage.

128 C'est bonne ordre que mariageBien dire l'ose.

ST. FIACRE

Pas encontre vous ne propose, Mais je sçay bien en verité

132 Que trop miex vault virginité:

Garder la veul de bon corage.

$N$ 'ay soing d'entrer en mariage,

Doulce seur gente.

LA PUCELLE

136 Mon amy, sy vous atalente,

Vostre fame de moy ferez- $57 \mathrm{c}$

De chascun miex prisiez serez

Se vous deportez gentement,

140 Qu'a vivre sy müaclement,

C'est grant doulour.
ST. FIACRE

Vous me requerez de folour,

Mais pas ne m'y acorderay.

144 Goute ne me marieray

Fors a Dieu et a Nostre Dame,

Qui lez leurs gardent de diffame

Et de vergongne.

\section{LA CHAMBERIERE}

148 Alons nous ent sanz point d'esloigne,

Et prenez congié a son pere.

Trop est de diversse matere

Quant sy faitement vous refuse.

152 Sa jonesse povrement use, Car il ne tient de luy nul conte. Plus tendra terre que un conte $S$ 'il vit a age.

\section{LA PUCELLE}

156 M'amie, vous dites que sage.

A son pere vois congié prendre. ** Cy parle au pere St. Fiacre

Sire, j'ay parlé sanz mesprendre

A vostre filz, maiz n'a courage

$160 \mathrm{De}$ soy bouter en mariage.

Voir, il m'a dit tout a delivre

Que en virginité veult vivre,

Et en mesaise.

LE PERE ST. FIACRE

$164 \mathrm{Ma}$ doulce suer, ne vous desplaise, Je vous pry que vous revegniez Souvent cy, et ne vous fegniez De monstrer ly samblant d'amour.

168 Je pensse bien que sanz demour S'avisera.

116. A line rhyming with contenance seems to have been omitted. Jubinal erroneously inverts 115 with the rubric. 


\section{LA VIE MONSEIGNEUR SAINT FIACRE}

LA PUCELLE

Sire, celle sui qui fera

De cuer la vostre volenté.

172 Mon vouloir est entalenté

Pour vous. Je voiz en mon repaire

Par cy. Dieu vous gart de

contraire

Par sa poissance.

ST. FIACRE

176 Vray Dieu, en qui j'ay ma crëance,

Donnez moy grace de tant faire Cy aval que vous puisse plaire.

Mon pere me veult marier

$58 \mathrm{a}$

180 Mais ne me veul mie lier

En mariage. Fol seroie

Se ma virginité perdroie.

Sy vous pry de vraie matere,

184 Et vostre glorïeuse mere,

Que me donnez voie tenir

Par laquelle puisse venir

A sauvement.

**DIEU (cy parle Dieu a sa mere)

188 Mere, voir, moult piteusement

Fiacre la aval me prie.

Son pere veult qu'on le marie

Afin que gaiement se porte,

192 Mais grandement s'en desconforte-

N'a soing d'orgueil ne de bobance

$\mathrm{Ne}$ de quarole ne de dance;

Ains veult demener sainte vie.

196 Sa virginité m'a plevie

De bon courage.

LA MERE DIEU

Mon chier filz, se sera domage

Sy se part de vostre service,
200. Quar bien vous sert sanz faire vice;

Pour l'amour de vous, het le monde,

Car bien voit qu'i n'i a riens monde.

Ottroiez ly conseil sy ferme

204 Que il puist sy user le terme

De sa vie, qui est mortele, Qu'il ait des ciex la joie belle, Qui tout temps dure.

DIEU

208 Bien m'y ottroie, c'est droiture.

Gabriel, fay, sy li va dire

Qu'il passe mer sanz contredire,

Et delaisse sa cognoissance,

212 Et face tant qu'il viegne en

France.

Et tel conseil y trouvera

Par lequel il se sauvera

Legierement.

GABRIEL

$216 \mathrm{Je} \mathrm{ly}$ vois dire vraiement

Ens en l'eure, quant vous agree.

De vous desdire n'ay penssee-

Foleur feroie.

**:ST. FIACRE

220 Glorïex Dieu, bien dormiroie.

Ycy endroit me coucheray-

Un petit me reposeray,

S'a Dieu agree.

GABRIEL

$58 c$

224 Dire me convient ma penssee

A Fiacre qui se repose.

Cy parle l'ange a St. Fiacre quant il sera couchié

184. MS: gloraise. p. 147.

216. On suppression of direct object pronoun when there is an indirect object, see Foulet, 


\section{LA VIE MONSEIGNEUR SAINT FIACRE}

Mon amy, Dieu, qui tout dispose,

Veult que lesses ceste contree

228 Et que passes la mer salee, Car, se cy endroit demouroies, Pas sy bien ne te sauveroies. N'en doubte pas, c'est chose voire.

232 De paradis, en la grant gloire, Ses cieulx revois.

\section{**:ST. FIACRE}

J'ay oïe moult doulce voix.

Bien croy que du ciel est venue.

236 Il dit que de cy me remue.

Quant a Dieu plaist, ne fineray

Devant que a la mer seray.

Vers le batelier me fault traire. ** Cy voise au batelier et die:

240 Amis, Dieu vous gart de contraire.

Sy vous plaist, vous me passerez Dela, et bien paié serez, Sanz estrif faire.

\section{LE BATELIER}

244 Entrez ens, frere debonnaire, 58d Bien et a point vous passeray (Pour l'amour de Dieu le feray Ou quel j'ay mise ma fiance)

248 Au port par ou en va en France, Car je croy, se Diex me pourvoie, Que n'avez pas moult de monnoie.

Je croy que de bon lieu soiez.

252 **Dieu nous a sy bien avoiez Que sommes a bon port venuz.
A li loer sommes tenuz, Car c'est raison.
ST. FIACRE

256 Adieu, frere, bien est saison Que je voise vers Miaulx em Brie. Avis m'est, n'en mentiray mie, Se l'evesque Pharon trouvoie,

260 Que par luy conseilliez seroie Bien et a point, sanz demouree, Car il a bonne renommee Jusques a Romme.

${ }^{* *}$ ST. PHARON

264 Sa voy venir un estrange homme. Il semble moult bien a sa chiere Que il n'ait mie foleur chiere. Il pert bien qu'il est traveillié;

268 Il a jeüné et veillié:

Bien y apert a son vïaire. $\quad 59$ a Je croy qu'il soit de bonne afaire. Il vient vers nous la droite voie-

272 Diex doint que tielz nouvelles oie Qui soient belles.

\section{LE CHAPELAIN}

Se Dieu plaist, il lez dira tellez De quoy liez et joieux seron.

276 Sus ses mos nous aviseron.

Avis m'est a sa contenance

Qu'il est homme de penitance;

Petit se prise.

ST. FIACRE

280 Un seigneur de devoste guise Voy la. Il fault que m'y conseille. Pour Dieu prier bien souvent veille.

Je li vois dire mon courage. Cy parle St. Fiacre a St. Pharon 284 Sire, Diex vous gart de dommage, Et vous doint sa volenté faire.

232-3. One might have expected $A$ paradis, en la grant gloire / Des cieulx revois. The initials, probably added later, may be errors.

259. Pharon, the fourteenth Bishop of Meaux, figures in the much discussed cantilena or Song of Burgundofaro. See Bédier, Légendes épiques, IV, 289-335; Porter and Baltzell, p. 21, n. 2 . 


\section{LA VIE MONSEIGNEUR SAINT FIACRE}

Recorder vous veul mon afaire En verité.

ST. PHARON

288 Dieu, qui est plain de charité,

Vous doint grace de dire chose

Qui soit bonne, car je propose:

Soing n'avez de dire foleur,

292 Car vous portez simple couleur Et agreable.

\section{ST. FIACRE}

Sire, sachiez: ce n'est pas fable. Je viens d'oustre la mer salee;

296 Touz mez parens et ma contree Ay lessié pour la Dieu amour, Sy m'en sui venu sanz demour. Bien say se demouré y fusse, 300 A servir Dieu lessié eüsse, Et ce fust pour moy grant folie. Ou non de la Vierge Marie Ay renoncié de bon memoire

304 A toute chose transitoire, Sy vous pry qu'il vous veulle plaire

Que en aucun lieu solitaire Soie mis ou face demeure, 308 Car j'ay desir que je labeure En servant Dieu toute ma vie, Car, voir, n'ay talent ne envie Dez biens du monde.

ST. PHARON

312 Amis, Dieu, ou tout bien abonde, En ce bon propos te maintiegne! Je ne veul pas que a moy tiegne. Suis moy; je te menray en l'eure $59 c$

316 En un lieu ou feras demeure Qui n'est mie hanté de gens. **Regarde cy, lieu y a gent. La terre t'est toute donnee
320 Que fourras en une journee Pour maison faire.

ST. FIACRE

Dieu, qui toute chose peut faire, Chier sire, le vous veulle rendre. 324 Un lieu faire vouldray entendre De bonne guise.

ST. PHARON

Restourner me fault a l'eglise. Mon chier amy, pour moy priez

328 Souvent, ne vous en detriez. Venez a Miaulx pour moy vëoir. Ja ne vous puist il meschëoir Pour chose nee.

LE CHAPELAIN

332 Alons nous ent, sanz demouree, Mon chier seigneur, par ceste voie.

Se jeune homme, que Dieu pourvoie,

A bon courage, sanz faintise.

336 Nous serons tantost a l'eglise, Qui est faite d'euvre moult chiere. **Seez vous en ceste chaëre, Se il vous hete.

$59 d$

ST. PHARON

340 Vostre volenté sera faite, Car elle n'est pas dissolue. Si m'asserray sanz atendue Pour repos prendre.

** ST. FIACRE

344 Il me fault foür sanz atendre De ceste besche qu'ay trouvee; Tel euvre n'ay pas a usee, Mais il convient que je l'apreigne.

348 Dieu me doint faire tel ouvrangne Qui li soit agreable et bonne. 


\section{LA VIE MONSEIGNEUR SAINT FIACRE}

Je croy que Dieu, qui tout bien donne,

Fait vertus pour moy, c'est sans doubte,

352 Car en lieu ma besche ne boute Que la terre ne se remue Tout par tout. C'est chose seüe:

A deux bescheez seulement, 356 Ay fouÿ de terre granment

A poy de paine.

LA VIELLE HOUdÉE

Sire, ce soit en pute estraine

Qui vous a ycy amené.

360 Il fault que vostre demené Sache l'evesque sanz atendre. $60 a$ Toute sa terre voulez prendre.

On puet vëoir a vostre guise

364 Qu'estez plain de grant convoitise,

Mais je feray tant vraiement

Que ne fourrez pas longuement. Je le vois querre.

\section{ST. FIACRE}

368 Je ne convoite pas la terre.

Fame, dictez quanque verrez,

Car ja nuire ne me pourrez, Se Dieu l'ottroie.

HOUDÉE

372 A Miaulx m'en vois par ceste voie.

A l'evesque le fait diray;

Ja de riens ne l'en mantiray. **Cy parle a l'evesque et die:

Sire, je suis a vous venue,

376 Car par guise trop dissolue

Fent cel omme qu'avez lessié.

Il destruit tout vostre plessié.
Sy fent longues ainssy, sanz doubte

380 Vostre terre vous toudra toute.

Venez y et sy le veez;

Chier sire, se ne m'en creez, Trop sui dolente.

ST. PHARON

384 Vëoir le vois, il m'atalente, $60 \mathrm{~b}$ Sy verray comment se deporte. Jhesucrist, qui lez siens conforte, Me veulle garder de meffaire.

388 N'aresteray pour nul contraire Tant que [je] voie la magniere. ${ }^{* *}$ Cy parle a St. Fiacre

$\mathrm{Par}$ Dieu, qui nous donne lumiere,

Fiacre, vous fectes merveilles.

392 Je ne vy oncques lez pareilles.

Vous estes de digne matere,

Car vous fectes, c'est chose clere,

$\mathrm{Ce}$ que homme ne pourroit faire. 396 Tout vostre plaisir me doit plaire Entierement.

ST. FIACRE

Le foür lairay vraiement.

Certes, pas a mal n'y penssoie, 400 Car pas volentiers ne feroie A vous ne a autre grevance.

Je prendray cy ma demourance, Chier sire, quant il vous agree, 404 Car j'ay desir et grant penssee De Dieu prier.

ST. PHARON

Je m'en revois sanz destrier.

Sains homs estes, j'en sui sceür. 408 Priez pour moy, n'aiez peür.

Se il vous vient nessecité,

$357 \mathrm{r}$. In other accounts of the life of St. Fiacre, the old woman is named Becnaude. See Porter and Baltzell, p. 24, n. 17. 
Et je le say en verité- $60 \mathrm{c}$ A vous venray.

ST. FIACRE

412 Sus ceste pierre me tenray;

Dessus feray ma reposee.

Vray, bien mole [je] l'ay trouvee-

Je cuidoie qu'elle fust dure.

416 Dieu qui nasqui de vierge pure

Vois prier, quar il est raison.

Ycy feray je ma maison,

Jamais ne m'en departiray.

$420 \mathrm{Cy}$ endroit mes heures diray De bon courage.

** LA PUCELLE

Je m'en revois en l'eritage

Ou le pere Fïacre hante,

424 Qui moult enviz s'esbat et chante.

$\mathrm{Ne}$ s'est sa maniere muee.

Chamberiere, sanz demouree,

Alons en sanz faire demour,

428 Car savoir veul sanz nul sejour

Comment Fïacre se deporte.

En ly vëoir me reconforteJe l'aing sanz faille.

LA CHAMBERIERE

432 Alons doncques, vaille que vaille, N'est pas raison que vous desdie.

$60 d$

De gré vous feray compaignie:

G'y sui tenue.

LA PUCELLE

436 Alons tout droit par ceste rue.

De Fïacre voy la le pere.

${ }^{* *}$ Cy parle au pere St. Fiacre
Sire, Dieu et sa doulce mere

Vous veullent ottroier grant joie.

440 Volentiers Fïacre verroye,

Pour lui vëoir sui sa venue,

Afin que son courage mue

Quant me verra.

LE PERE ST. FIACRE

444 Je ne sçay ou en le querra;

Tout a lessié son tenement;

Alez s'en est secretement.

Je ne sçay qu'il est devenuz.

448 Tous sez amis groz et menuz

A deguerpis par sa foleur.

J'en ay en mon cuer grant douleur

Et fort despit.

LE MESSAGIER

452 Sire, sachiez que l'en me dist

L'autrier quant fu en Miaulx em Brie,

Qu'un jeune homme de sainte vie,

$61 a$

Qui estoit Fïacre nommé,

456 A deux lieues de la cité

Demouroit en un hermitage.

A l'evesque, qu'en tient a sage,

Conta qu'ost sa terre lessie

460 Pour ce que il ne vouloit mie

Espouser une fille belle.

Qui en vouldra oïr nouvelle,

La le voit querre.

\section{LA PUCELLE}

464 Tant yray par mer et par terre, Sy plaist a Dieu, que g'i seray. Par foy jamais ne fineray Tant que je voie l'ermitage.

412. The stone is still displayed in the church at the hamlet of St.-Fiacre near Meaux, with the tomb of the Saint.

425. MS: Ne s'ay, which may be a scribal error, or the line means "Moi, je n'ai pas changé. . . ." 


\section{LA VIE MONSEIGNEUR SAINT FIACRE}

$468 \mathrm{Au}$ port m'en vois sans arrestage. ** Cy parle au batelier

Amis, passe nous sans atendre, Que de mal nous veulle deffendre Le Roy dez Roys, qui tout puet faire,

472 Et tu en avras bon salaire, Saches sanz doubte.

LE BATELIER

Vostre volenté feray toute.

Entrez en la nef sanz demeure,

476 Sy passerons en la bonne heure,

Tandis comme bon vent avon,

Car pas de certain ne savon

Se nous l'arons tel longuement.

$480 * *$ Venus a port de sauvement, Dieu mercy, sommes.

LA PUCELLE

Il est droit que nous vous paiomes.

Tenez, amiz, pour nous priez, 484 Et sy vous pri que nous diez Par ou yrons a Miaux em Brie. N'ay talent que gaires destrie Tant que g'y soie.

\section{LE BATELIER}

488 Alez toute ceste grant voie Et vous ne pourrez forvoier. Que Dieu vous veulle convoier Sanz destourbance.

\section{LA PUCELLE}

492 Adieu, frere. Cotoier France Nous convendra, m'amie chiere. Cy parle a sa chamberiere Volentiers verroie la chiere De Fiacre que nous querons.
496 Se Dieu plaist, nous le trouverons; G'y mettray paine.

***T. FIACRE

Je voy venir par celle plaine

La pucelle qui a desir $61 c$

500 Que avec ly voise gesir;

Mais n'ay talent de moy soullier. Icy me vois agenoullier Pour prier Dieu devotement.

504 Vray Dieu, sy vray que fermement

Croy que nasquites de la belle Qui enfanta, vierge pucelle, Vostre saint corps sanz souffrir paine;

$508 \mathrm{Et}$ qu'onques franche ne villaine Ne pot dire, par verité, Qu'enfantast en virginité Fors elle; ne donnez puissance

512 A celle qui a esperance De moy trouver, qu'en nulle guise

Me recognoisse ne ravise, Car se de luy connus estoie, 516 De li trestant semons seroie. Espoir qu'encliner me feroit, A fait de quoy pis me seroit Et grant domage.

LA PUCELLE

520 Je croy que c'est la l'ermitage A deux lieues de Miaulx em Brie.

Est ainsinques le devisoit

524 Le messager quant il disoit Oultre la mer dont sui venue. $61 \mathrm{~d}$ Aler m'y fault sanz atendue, Suer debonnaire.

522. A line rhyming with Brie seems to have been omitted. disoit.

524. The scribe deleted passoit, perhaps misreading a parloit in his copy, and substituted 
LA CHAMBERIERE

$528 \mathrm{Ne}$ sommes pas loing du repaire. Alons y quant vous atalente; Metons a li trouver entente. Quant avez fain de li trouver, 532 Nous nous en devons esprouver Sanz terme prendre.

\section{LA PUCELlE}

Aler m'y convient sanz atendre;

J'enterray ens.

Cy entre

\section{**Dieu Nostre Pere}

536 Soit sëans et sa doulce mere. Ycy endroit venue estoie Pour la cause que je cuidoie Trouver ce que ne trouve mie.

$540 \mathrm{Je}$ me sui en vain traveillie Se vous ne m'enseigniez un home Que le commun Fïacre nomme.

A deux lieues de Miaulx demeure,

544 En hermitage la äeure Le Roy des Roys.

\section{ST. FIACRE}

Dame, bon fait fouïr des rois. 62a Mais, se Dieu me gart de dommaige,

548 N'a en ce païs hermitage Fors que cestui. Fole serez Se nul autre plus enquerez, Qu'il n'y est goute.

\section{LA PUCELLE}

552 J'ay perdue ma paine toute, Car, voir, Fïacre n'estez mie. Il nous en fault aler, amie. Fïacre n'a pas tel visage 556 Comme l'omme de l'ermitage, Je sui sceüre.
** ST. FIACRE

Hé, glorieuse Vierge pure, Louer vous doy et mercier:

560 Pas ne me voulez oublier. Or sçay je bien certainement Que demourer sceürement Puis bien ycy toute ma vie.

564 Bien sçay la pucelle polie Plus ne vendra pour moy trouver. D'or en avant me doy prouver De faire le salut de m'ame, 568 Car je pensse que homs ne fame N'y mettra plus enpeschement. Plus ne revandra vraiement $62 \mathrm{~b}$ La damoiselle.

\section{**DIEU (en parlant a sa mere)}

572 Mere, forment vie cruelle Maine Fiacre pour m'amour. Il ne fera pas grant demour La jus en la vie mortelle:

576 Il ara la cellestielle, Quar il a assez deservie. Onques ne vost user sa vie La jus fors en afflicion.

580 Bonne remuneracion

En doit avoir.

\section{LA MERE DIEU}

Il a esté plain de savoir Et est encore sanz faulz vice. 584 A esté en vostre service Et ou mien par bonne penssee. M'a devotement saluee Plusieurs fois [et] de bon courage.

588 Pour tant vous pri que du servage A l'ennemy soit deffenduz, Car du tout c'est a vous renduz, Sanz nul moien. 
DIEU

592 Ja ne charra ou faulx loien $62 \mathrm{c}$

Du felon Sathan ennemy,

Qui n'a bon sergent ne demy.

Guieres ne demourra en vie.

596 Pharon l'aime, je n'en doubt mie, Sanz tricherie.

***sT. FIACRE

Soupris me sent de maladie.

Il fault que je soie couchiez.

$600 \mathrm{Je}$ vous pry, vray Dieu, que touchiez

Ne soit mon corps de famme nee,

$\mathrm{Ne}$ que nulle ne soit entree

Ou lieu ou je reposeray.

604 Ycy endroit me coucheray; Las! Corps, moult poises!

\section{***DIEU}

Michiel, il convient que tu voisez,

Toy et Gabriel, a Pharon,

608 Et ly dy que briefment aron

De Fïacre bien briement l'ame.

De li savoir ne veul diffame.

Qu'il li port le saint sacrement,

612 Et soit a son trespassement,

Et qu'il li face son service

Bien et a point, sanz nes un vice. Mieux en vaura.

ST. MICHIEL

$62 \mathrm{~d}$

616 Alons, compains, pas ne faura

A nous que nous ne voison dire. ** Cy parlent a Pharon Michiel et Gabriel

Pharon, saches que Nostre Sire

Veult que de toy soit visité

620 Fïacre, car, en verité,

Pas longuement [il] ne vivra.
De par toy porté li sera

Le saint sacrement, c'est raison.

624 Et ne te part de la maison

Devant qu'il sera enterré.

Il a le cuer de mal serré.

Va le vëoir.

ST. PHARON

628 Il me devroit bien meschëoir

Se le plaisir Dieu refusoie.

Tantost yray, se je targoie

Je feroie haulte folie-

632 J'ay la voiz des anges oïe.

$C y$ parle a son chapelain

Chapelain, avec moy venez,

Et nostre clerc y amenez

Par compaignie.

LE CHAPELAIN

$63 a$

636 Haston nous! Se il perdoit vie Ains que nous y fussions venuz, Pour faulz en serions tenuz.

Cy parle au clerc

Clerc, vien avec nous sanz atendre.

640 L'iaue benoiste te fault prendre

Sanz respit faire.

LE CLERC

Et je le feray sanz contraire. Certes moult volentiers feray

644 Tout ce a quoy tenu seray. Avançons nous d'aler au lieu, Puis que c'est le vouloir de Dieu, Qui nous pourvoie.

ST. PHARON

$648 \mathrm{Ne}$ fineray tant que g'i soie;

Alons par ce chemin ferré.

610. MS: veult. The line seems to mean, "Je ne veux pas qu'il soit déshonoré"; or De li might be taken as reinforcing De Fiacre in 609 , in which case veult might remain to make the line mean, "Il ne veut pas être déshonoré."

617. r. MS: parle. 
J'aroie trop le cuer serré

Se mon devoir ne li fesoie.

$6522^{* *}$ Je le voy, Jhesus le pourvoie.

Il le me fault araisonner. Cy parle a St. Fiacre et die:

Frere, Dieu, qui puet pardonner

Touz meffaiz par sa courtoisie,

$63 \mathrm{~b}$

656 Veult que soiez de sa partie.

Venu sui pour vous visiter;

Devostement sanz respiter, Feray l'afaire.

ST. FIACRE

660 Mon trez chier seigneur debonnaire,

Chargié sui de grant malladie.

Estre ne puis longues en vie-

Trespasser me fault temprement.

664 Bailliez moy le saint sacrement,

S'en fineray plus asseür

Contre l'anemy qui peür

M'a fait souvent.

ST. PHARON

668 Vous l'arez, je vous en couvent, Volentiers et a bonne chiere. Vous creez en bonne maniere Que c'est cil, ne n'en doubtez mie, 672 Le filz de la Vierge Marie, Qui pour faire repdempcion Aulx humains suffry passion, Puis au tiers jour resuscita, $676 \mathrm{Et}$ quant il voult, es cielx monta, Et siet a la destre son pere, Et revenra, c'est chose clere, 63c Quant temps sera, par bon avis,

673. MS: repdemcon.

709 r. See Appendix: Historical Notes.
680 Pour juger trestous mors et vis Au jugement.

ST. FIACRE

Ainssy le croy je fermement, Sanz nulle faille.

ST. PHARON

684 Mon chier amy, je le vous baille: Il est bien temps que le pregniez. Usez le bien, ne vous feigniez, Mon tres chier frere.

ST. FIACRE

688 J'ay de joie faire matere, Car j'ay les anges parceüz, Dont mon esprit iert receüz. Finer veul le chief encliné.

692 In manus tua, Domine, Commendo spiritum meum.

**sT. MICHIEL

Gabrïl, quant s'ame veon, Sy la porton la sus en gloire. 696 Tous jours a eü en memoire De Jhesuscrist la passion. $\mathrm{Ne}$ faison plus dilacion $63 \mathrm{~d}$

De porter l'en a bonne chiere 700 Devant Dieu en vraie lumiere, Qui point ne fine.

ST. PHARON

Ensevelir sanz lonc termine Nous fault Fïacre, c'est raison.

704 N'y avons pas mis grant saison. S'ame reçoit hui moult bon offre. Mettre le convient en ce coffre, Puis de ce drap le couverron. 708 Apres, cy entour nous serron, $\mathrm{Ne}$ vous desplaise. 


\section{LA VIE MONSEIGNEUR SAINT FIACRE}

${ }^{* *}$ CY EST INTERPOSE UNE FARSSE

LE BRIGANT

Biau preudom, je ne sui pas aise:

J'ay perdue ma compaignie.

712 Ensaigne moy, ne [me] ment mie,

Le droit chemin a St.-Omer, Par Dieu que chascun doit amer.

De forvoier sui en doubtance, 716 Car oncques mais ne fu en France N'en Picardie.

LE VILAIN

Je mengeray de la boulie

$64 a$

Ja quant je vendray a maison.

720 Mais j'ay perdue ma saison

De tous poins ceste matinee,

Car le prestre sy a chantee

Hui au matin trop longue messe.

$724 \mathrm{Ne}$ prise le cry d'une asnesse

Tout quanqu'il pourroit

sermonner.

Il ne pensse qu'a organer

Pour traire nostre argent de boursse.

728 Aussy tost aroit un pet d'oursse Qu'ait riens du mien par son abet, Tant sache chanter au fausset N'a haulte alaine.

LE BRIGANT

732 Bons homs, dy moy, ne te soit paine,

Par ou sont lez brigans passez?

Je sui d'estrier tous lassez.

Ensaigne moy, que Dieu te voie, 736 De St.-Omer la droite voie.
(Se vilain respondre ne daigne:

En mon cuer en ay grant engaigne.

Sourt est, je croy.)

LE VILAIN

740 Queurs tu apres un palleffroy?

$\mathrm{Tu}$ as robe bien escourtee-

N'aiez doubte qu'elle soit crotee.

Tu sembles moult bien plain d'oultrage-

744 Je ne sçay se tu as courage De moy ferir en nulle guise.

Mais en verité te devise

Que, se de toy feru estoie,

748 De mon houel $t[e]$ abatroie

Le hasterel.

LE BRIGANT

(Se felon vilain boterel

Me tient bien, ne me veult mot dire.

752 Voir, [il] me fait au cuer grant yre;

Encore l'araisonneray.)

Bons homs, dy, par ou passeray

Pour mez compaignons retrouver?

756 Je le te vouldroie rouver Par courtoisie.

LE VILAIN

Ma fame maine grant mestrie Suz moy, s'en sera tourmentee;

760 Quant je veul pois, n'ay que poiree.

Trop me desprise malement,

Sy en ara grief paiement En brief termine.

713. See ibid.

737. MS: ne daigne respondre, changed to preserve rhyme.

751. M'entent, instead of Me tient, would improve the sense. 
LE BRIGANT

764 Faulx vilain, la male courrime

Te puist tenir et le lampas.

Pour quoy ne m'ensaignes tu pas

$64 c$

Mon chemin? (Chose que je die, $768 \mathrm{Par}$ foy, ne tient qu'a moquerie.)

Je te ferray ains que m'en aille.

En fourme de vilain, sanz faille, Es bien taillié.

IE VILAIN

772 Se mon pain t'avoie baillié, Moult mal asseuré en seroie, Car ataindre ne te pourroie, J'en sui sceür.

\section{LE BRIGANT}

$776 \mathrm{Par}$ foy, se n'eüsse peür Que de justice repris fusse, Je te tranchasse la capusse De ma coustille de randon. 780 Mais j'enporteray a bandon Se chapon cras, sanz demouree. Mengié sera a la vespree Quant l'ay trouvé.

LE SERGENT

$784 \mathrm{Tu}$ sembles bien larron prouvé. Pas le chapon n'enporteras; Ja la gorge n'en passeras. Fay, met le jus, ribault pourry; 788 A ceulz sera qui l'ont nourry. Entre vous brigans, n'en dout mie, $64 d$

$\mathrm{Ne}$ vivez que de roberie.

Lessez le chapon sans attendre,
792 C'on te puist par la gorge pendre, Garsson puant.

\section{LE BRIGANT}

En me devroit aler huant

Se le chapon pour toy lessoie.

796 Je le mettray en my la voie

Tant que me soie conbatu.

Se ton orgueil n'est abatu

Par moy, chetif sergenterel, $800 \mathrm{Je}$ ne me prise un vielz merel Se n'as du pire.

\section{LE SERGENT}

Tien, jamais sanz conseil de mire De ce coup n'avras garison.

$804 \mathrm{Ta}$ coustille petit prison.

Le chapon n'enporteras mie. Petit priseroie ma vie

Se cy endroit tort me feroiez;

808 En ton païs bien le feroiez, Quant ycy endroit le veulz faire. Pour tant en aras tel contraire Que tu mourras.

\section{LE BRIGANT}

812 Ja deffendre ne te pourras 65 a

Contre moy. (Se saigne un petit!)

Tant ay je plus grant apetit

De moy venger, bien dire l'ose!

816 Se m'as priste aucune chose, Moult bien m'en saray aquiter. Il te couvient a moy luitier; Puis que je te tiens, tu charras. 820 Plus d'espee ne me ferras.

Petit te prise.

766. MS: ensaigne.

768. MS: tieng.

807-8. The scribe may have erroneously copied feroiez twice. The lines seem to mean, "J'estimerais peu ma vie si tu me faisais du mal ici; en ton pays tu le ferais bien, puisque tu veux le faire ici."

814. Despit was deleted by the scribe and apetit substituted. 


\section{LA VIE MONSEIGNEUR SAINT FIACRE}

LE SERGENT

Je sçay bien de luitier la guise;

Quant je te tiens, petit te doubte.

824 Il fault que le chapon te couste

vilainement.

LE BRIGANT

Garde toy bien! Prochainement

$\mathrm{Te}$ verras verssé contre terre.

$828 \mathrm{Tu}$ ne sces mie moult de guerre-

Tien sela et sy te deporte!

Mais je te dy bien et enorte

Que de droit doiz paier ton lit.

832 Je m'en yray sy t'enbellit,

Et se il ne t'enbellit mie;

S'enporteray de ma partie

Le chappon cras.

LE SERGENT

$65 b$

836 Haro! Il m'a rompu le bras!

De luitier a lui fiz folie.

Le chapon a par sa mestrie.

S'en pais li eüsse lessié,

840 De miex m'en fust, car abessié

Mon nom grandement en sera.

Bien sçay qu'en m'en desprisera.

Pour fol le cuidoie tenir-

844 Meschief m'en devoit bien venir.

Il est huy, tant me sui prisié,

Qu'en ay eü le bras brisié.

Veez comme scet bien fouï;

848 Je ne le pourroie suir-

Voit au diable!

** LA FAMME AU VILAIN

Doulce commere, n'est pas fable-

Vostre mary est mahengnié.

852 Il cuidoit avoir gäangnié

Contre un brigant par sa foleur
Un cras chapon, mez grant douleur

L'en est soursse, pas n'en doubton,

856 Sy n'i a conquis un bouton, Mais grant contraire.

LA FAME AU SERGENT

Dieu veulle qu'il puist tel fait faire

Que en le pende par la gorge! 65c

860 Le glorïeux martir, St. George,

Et la doulce Vierge Marie

Veullent qu'il face tel folie

Que mourir puist vilainement,

864 Bien tost, et bien appertement,

Qu'il me maine trop dure vie Pour une garsse qui n'est mie Sy belle comme moy d'assez.

868 Il a plus de trois ans passez

$\mathrm{Qu}$ 'i la gouverne.

LA FAME AU VILAIN

Ma suer, je sçay une taverne

$\mathrm{Ou}$ il a un moult sy frïant

872 Qu'a touz corps fait le cuer rïant

Qui en avalle.

LA FAME AU SERGENT

Voir, j'ay de duel la couleur palle,

Car essoir fu trop bien batue;

876 Pour tant loue Dieu et salue

Quant mon mary a grief sondee.

Je ne seray mes huy frapee

De li, puis qu'a le bras brisié.

$880 \mathrm{Du}$ moult que tant avez prisié,

Veul aler boire.

LA FAME AU VILAIN

Commere, c'est vers St. Magloire.

862. MS: facent.

879. MS: $p$. qu'as, with $-s$ deleted by the scribe.

882. See Appendix: Historical Notes. 


\section{LA VIE MONSEIGNEUR SAINT FIACRE}

Alons tost, car c'est le filz Dieu.

884 Fain ay que soie sus le lieu

$\mathrm{Ne}$ dout point que batue soie.

Pour mon mary riens ne feroie,

$\mathrm{Ne}$ me fiert goute.

** LA FAME AU SERGENT

888 Entrons ens; trop le mien redoubte:

Trop me bat, ne s'en peut tenir. Male honte li puist venir, Et au brigant soit ajourné

892 Bon jour qui sy l'a atourné, Car j'en ay a mon cuer grant joie!

Cy parle a la taverniere

Taverniere, se Diex vous voie,

En un lieu privé nous metez,

896 Puis a boire nous aportez

A bonne chiere.

LA TAVERNIERE

En ceste chambre cy derriere

Vous seez, lieu y a privé.

$900 \mathrm{Ja}$ a vous n'ara estrivé.

En l'eure servies serez

De ce que vous demenderez

Sanz demouree.

$66 a$

LA FAME AU VILAIN

904 Faites que nous soit aportee

Une pinte de moult vermeil.

Je ne beu ouan son pareil

En ceste ville.

LA TAVERNIERE

908 Volentiers l'arez, c'est sanz guille. Je vois querre la pinte plaine.

$C y$ voise querre du vin et puis die:

883. I.e., "C'est la fête du fils de Dieu."

887. Fiert may be a pun with the meaning both of battre and convenir.

932. This line seems to mean: "Mon mari fut cruel envers nous."

933. MS: amee, with final -e deleted.
Tenez, buvez a bonne estraine Paisiblement.

LA FAME AU SERGENT

912 Vous buvrez tout premierement, Commere, vous estes l'ainee. Aussy $\mathrm{m}[\mathrm{e}]$ avez aportee La nouvelle premierement

916 De mon mary qui malement Est atourné. J'en ay grant feste: Je vouldroie qu'eüst la teste Parmy brisiee.

LA FAME AU VILAIN

920 Buvez bien, commere prisiee; 66b Que Dieu confonde noz maris! Emplons de ce moult noz baris, Car il est fin.

LA FAME AU SERGENT

924 J'en empliray sy mon coffin Que seray yvre, bien le pensse. Se mon mary me fait offensse, Ou veult estriver de riens nee, 928 Puis que il a brache brisiee, Contre terre le bouteray. Jamais ne le deporteray,

Se me gart Diex.

LA FAME AU VILAIN

932 Mon mary fuet en noz tourtiex: Oncques ne fut de moy amé. Il vendra ja tout affamé, Mais ne m'en chault.

LA FAME AU SERGENT

936 Buvon ce moult frïant et chault; Mal ait qui bien ne [le] buivra. Je croy que grant bien nous fera. Quant je l'avale, j'en ay feste. 
940 Il m'est ja monté en la teste,

A paine me puis soustenir.

Et sy voy mon mary venir, $66 \mathrm{c}$

Tout droit dedens ceste taverne.

944 Assez fierement se gouverne:

$\mathrm{Ne}$ semble pas qu'ait bras quassé.

Il ne semble pas trop lassé-

Je sui perdue!

LA FAME AU VILAIN

948 Aussy voy je sanz atendue

Le mien droit sy a nous venir.

Chaude fievre le puist tenir!

Il m'a moult bien aparceüe.

$952 \mathrm{Je}$ croy que je seray batue.

Il vient des chans.

LE VILAIN

Par foy, je suis bien meschëans-

Aulx chans me tue chascun jour,

956 Et ma fame prent son sejour

Es tavernes, c'est chose voire.

Je la voy la en present boire

Le fort moult, mez s'el n'est latree,

960 Riens ne vail. Hé, gloute prouvee,

Il te convient mon poing sentir.

Cy bate sa fame

Je [ne] pourroie consentir $66 \mathrm{~d}$

Ta lecherie.

LA FAME AU VILAIN

964 Lasse! Je suis toute estourdie

Et afolee.

\section{LE SERGENT}

Fame, qui t'a cy amenee?

Voir, de toy sui petit prisié,

968 Combien qu'aie le bras brisié.

En frapant et en li ostant sa coiffe
S'aras tu de moy se merel:

N'i ara coife ne bourel

Que ne despiesse.

LA FAME AU SERGENT

$972 \mathrm{Sa}$, commere, qu'i vous meschesse Quant vous m'avez cy amenee! Je n'avoie mie penssee

Que mon mary me peüst batre.

976 Il me convient a vous conbatre;

Autel qu'i m'a fait, vous feray,

Car a mez mains vous pigneray

Vos nerfz cheveux.

LA FAME AU VILAIN

980 Foy que je doy tous mez neveus, La bonté vous sera rendue! $67 \mathrm{a}$ Par terre serez abatue,

Se le puis faire.

LA FAME AU SERGENT

984 Doulce commere debonnaire, Apaisons nous, et sens sera. $\mathrm{Mal}$ ait qui plus estrivera. Et chantons com desconfortees:

988 Mauvaises coiffes dessirees

Avons par lez mous.

\section{CY FINE LA FARSSE}

\section{***DIEU}

Le corps Fïacre, qui fut doulz,

Fault honnourer de bonne guise.

992 Vous deux archanges que je prise, Alez a Pharon reciter

Que il lieve sanz respiter

Le corps St. Fiacre briement.

996 Pour ce qu'a usee griement

Sa char la jus aval en terre,

951. MS has a bar across $p$ in aparceüe and, in addition, par is written in the word. 962 and 963 are written as one line in the manuscript. 


\section{LA VIE MONSEIGNEUR SAINT FIACRE}

Veul que l'en voit son corps requerre,

Et qu'on l'onneure.

GABRIEL

1000 Volentiers yrons sanz demeure

A l'evesque vostre gré dire. $67 \mathrm{~b}$ Bien sçay qu'il n'en ara pas yre. Alons y droit sanz plus atendre. **Cy parlent a Pharon

1004 Pharon, pour voir te fois entendre Que Jhesucrist veult vraiement Que St. Fiacre soit briement Hors du lieu ou il gist levez.

1008 Corps qui sera de mal grevez, Par le plaisir Dieu, garira.

Personne qui de cuer yra

De bon cuer le bon Saint requerre,

1012 Ystra de meschief et de guerre Au Dieu vouloir.

\section{ST. PHARON}

Je le feray sanz moy douloir Volentiers, car il est droiture.

$1016^{* *}$ Seigneurs, a la bonne aventure

St. Fïacre translateron,

Du lieu ou il est l'osteron.

En ceste chace sera mis,

1020 Car, voir, il est de Dieu amis.

Or tost, aidiez moy sanz default. **Sus cel autel mestre le fault.

Avançons [nous], que Dieu vous voie.

1024 Des malades par mainte voie

Le vendront cy endroit requerre,
Car bien usa son temps en terre:

Bien le savon.

LE CHAPELAIN

1028 Monseigneur, moult bien mis l'avon;

Bon fait bien ouvrer en sa vie:

Lassus est s'ame hebergie,

Et le corps sera honnouré.

1032 Voir, touz ceulz sont bieneüré

Qui a Dieu servir veullent tendre. Noble loier leur en scet rendre, Et agreable.

LE CLERC

1036 C'est bien parole veritable: Quiconques fait bien, il le treuve. Dieu veulle que fasson tel euvre Qui au doulz Jhesucrist puist plaire.

1040 Devers le corps saint verrons traire

Des malades grant quantité.

Un mesel qui a cliqueté

Voy venir par celle sentelle.

1044 Saint Fïacre de cuer apelle. Il vient grant erre.

LE MESEL

Saint Fiacre, pour vous requerre Sui venus en ceste partie.

1048 Chargié sui de meselerie;

Moult a lonc temps qu'i moult me grieve.

Dieu, par qui le cler soleil lieve,

Et vous me veulliez alegier.

1004. Fois for fais.

1008. MS: seront.

1025. MS: vendrons.

1026. The scribe seems to have attempted to write temps over an error he had made; then when that was not clear, he wrote temps above the line. 


\section{LA VIE MONSEIGNEUR SAINT FIACRE}

1052 Je soloie estre moult legier

En ma jouvence.

ST. PHARON

Metez au Saint prier entente,

Et je croy qu'il vous aidera.

$1056 \mathrm{Ja}$ vostre mal tel ne sera

Que n'en aiez alegement.

Offrez au Saint seürement, D'entente fine.

LE MESEL

1060 Sy voir que je le tieng a digne,

De cire ma longeur li baille

A celle fin que il me vaille.

Sy voir que c'est de bon courage,

1064 Avis m'est que de mon visage

Chiet la raffle, Dieu soit loez.

Bonnes gens, veez et ouez

Le miracle que Dieu a fait;

1068 Pour St. Fïacre tout a fait.

De bonne heure sui sa venuz,

Que tout sain y sui devenuz.

$C y$ preigne congié et s'en voise

un pou avant et puis die:

Adieu, je m'en vois a grant chiere.

1072 Aulx gens conteray la maniere

Partout la ou je passeray. $\quad 68 \mathrm{a}$

Bonnes gens, voir vous conteray:

St. Fiacre m'a envoïe

1076 Garison de ma maladie

Vilaine qui tant m'a tenue.

Se nulle grieté vous argue,

Alez $y$, et garis serez,

1080 Se de bon cuer le requerez,

Sachiez sanz doubte.

***'AVEUGLE

Lonc temps a que [je] ne vy goute

Qui m'y menast la droite voie.
1084 Certes moult volentiers yroie Pour clarté prendre.

LE POTENCIER

Voir, je t'y merray sanz atendre.

Met dessus m'espaule ta main.

1088 N'aresteray ne soir ne main

Jusqu'a tant qu'en son monstier soie.

Savoir mon se j'en gariroie

Du mal qu'endure.

\section{L'AVEUGLE}

1092 Ce soit a la bonne aventure!

Alons, doulz frere debonnaire,

Dieu nous doint tel voiage faire

Qui nous pourfite.

$68 \mathrm{~b}$

** LE POTENCIER

1096 Biau lieu a cy, moult me delite;

Bien sommes venuz sanz demeure.

Agenoillier nous fault en l'eure.

Devant le Saint sommes venuz,

$1100 \mathrm{~A}$ li prier sommes tenuz.

E, St. Fïacre, qui jadis

Feïstes tant qu'en paradis

Est l'ame de vous hostelee,

1104 Priez Dieu que santé donnee

Me soit briement.

\section{L'AVEUGLE}

Sire, sy voir comme griement Ay lonc temps usee ma vie

1108 Au filz de la Vierge Marie,

Priez tant pour moy que je voie.

Bien ay emploiee ma voie,

Car je voy bien et clerement.

1112 Loez soit Dieu, qui point ne ment,

De cest ouvrage.

1077. For agreement of past participles with subject in compound tenses having avoir as auxiliary, see Sneyders de Vogel, p. 205. 


\section{LA VIE MONSEIGNEUR SAINT FIACRE}

\section{LE POTENCIER}

Aussy doy je de bon courage

Dieu et St. Fiacre prisier.

1116 Plus ne me faudra debrisier

Sus potences; n'en ay que faire.

Dieu doy louer de cest afaire

Bien fermement.

**'LA BOURGoISE DE LANGNY 68c

1120 A Langny ay moult longuement Hanté et prise demouree, Mais oncques crëature nee

N'y vint de quoy point miex vasisse.

$1124 \mathrm{Ne}$ truis qui ma jambe garisse $\mathrm{Du}$ mal qui est [et] let et acre. Aler me fault a St. Fïacre;

Ne fineray tant que g'i soie.

1128 **Doulz Saint, je vous pry que ma voie

Aie cy endroit emploïe

Tant que ma jambe soit garie.

Dieu a fait vertu bien pleniere:

$1132 \mathrm{Ma}$ jambe sanz toute legiere.

A Dieu et au bon Saint doy rendre

Grans graces de cuer sanz mesprendre,

Quant la voy saine.

** LA DAME CHEVALERESSE

1136 Chamberiere, ne te soit paine:

A St. Fiacre droite voie

Veul aler. Volentiers saroie,
Par la foy que doy Nostre Dame,

$1140 \mathrm{Qu}$ 'il avendroit a une famme

Qui enterroit en sa chapelle.

S'y bousteray ma damoiselle,

N'y fauldray mie.

LA CHAMBERIERE

1144 Je vous porteray compaignie Moult volentiers, se Diex me voie.

St. Fïacre de cuer verroie. Il fait plenté de vertus belles,

1148 Car fieuses grans et meselles Garit, contrais fait droit aler, Et aussy les müez parler, Et lez aveugles enlumine.

1152 Plain est de la grace divine, Se Dieu me voie.

LA CHEVAlERESSE

Alons y droit par ceste voie; Voir, assez briement y seron.

1156 Je te diray que nous feron:

Va t'en a l'uis de la chapelle, S'y atache ceste chandelle Sanz destrier.

LA CHAMBERIERE

1160 Il ne m'en convient pas prier. Moult devostement le feray. **Par cy or endroit meteray La chandelle qui est bien belle. 1164 N'enterray pas en la chapelle, Qu'i ne me couste.

1119. r. Lagny, between Paris and Meaux, had a monastery founded by St. Fursy, another Irish monk who, like Fiacre, came to the Continent during the seventh century. See Paetow, pp. 162-63; Molinier, I, 146; Chevalier, II, col. 1613, for further references.

1129. MS: emploiee, which seems to be an error on the part of a scribe accustomed to writing Francien.

1138. It was a tradition that no woman should enter the sanctuary. See lines $600 \mathrm{ff}$., and Porter and Baltzell, pp. $24 \mathrm{f}$.

1139. Preposition a before Nostre Dame deleted for meter.

1148. On the fic or mal St.-Fiacre, see p. 2 above.

1152. The scribe first wrote $d i d$, then covered the second $d$ with a heavy $v$ to make divine. 


\section{LA VIE MONSEIGNEUR SAINT FIACRE}

LA DAME CHEVALERESSE (en la boutant)

Sy feras; il fault que t'i boute. Moult sui legiere.

LA CHAMBERIERE

$69 a$

$1168 \mathrm{Je}$ m'en restourneray arriere.

Sanz raison $\mathrm{m}$ ['y] avez boutee.

J'ay esté forment effraee

Pour cest afaire.

LA CHEVALERESSE

1172 Haro! lasse! ne sçay que faire!

A bien petit que je n'enraige.

J'ay entrepris trop grant haussage.

Par droit me doy lasse clamer;

1176 Chascun me doit bien diffamer,

Et apeller fole musarde.

Tant ay mal que l'eure ne garde Que perde vie.

\section{LE CHAPELAIN}

1180 Arrestez vous yssi, m'amie.

$\mathrm{Ne}$ breez plus, ne ne criez.

A genous le bon Saint priez-

Il vous fera alegement.

1184 Ouvré avez moult folement Par estoutie.

\section{LA CHEVALERESSE}

Doulz St. Fïacre, je vous prie

Qu'alegement me veulliez faire,

1188 Et je vous promet $\operatorname{sanz}$ contraire Qu'offrande vous aporteray,

Et vostre feste garderay

Devostement chascunne annee,

1192 Tant com pourray avoir duree.

Je me repent de ma foleur.

Alegee de ma douleur

M'a St. Fiacre grandement.
1196 Je le doy louer bonnement Et mercier.

** LA FAME QUI PRIE SON MARY Monseigneur, je vous veul prier Que je voise, maiz qu'i vous plaise,

1200 A St. Fïacre. Grant mesaise

De son mal en mon corps endure.

Je pensse, se d'entente pure

Le requier, que seray garie.

1204 Lonc temps a que je sui saisie;

J'en sui certaine.

LE MARY

Or, vous souffrez en pute estrainne:

En St. Fïacre ne me fie

1208 Ne qu'en une chienne enragie.

De moy n'est amé ne prisié.

S'il avoit un gobet brisié,

De paradis banis en l'eure

1212 En seroit. Fol est qui l'oneure: Il n'est requis que de mardaille, Et a la fin, sachiez sanz faille, Mie n'irez.

LA FAME

1216 Sy vous plaist, autrement direz. Monseigneur, fol est qui desprise Les sains, que le Roy des Roys prise, Par son vouloir.

\section{LE MARY}

1220 Le cuer me prent fort a doloir! Il me venra grief et doumache! Il m'est avis que en m'esrache Le cuer; ne sçay que devenir1224 La male mort me puist tenir Hastivement. 


\section{LA VIE MONSEIGNEUR SAINT FIACRE}

LA FAME

Sire, parlez plus sagement,

Et ne vous desesperez mie.

1228 Le Saint vous fera courtoisie,

Se le priez.

\section{LE MARY}

G'iray sanz estre detriez,

Moy et vous en portant offrende

1232 Au Saint. N'ay mez douleur si grande

$\mathrm{Ne}$ tel contraire.

* LE ChanoINe

Un livre voy en celle aumoire;

Il convient que je le deslie.

1236 Voir[e], c'est d'un meschant la vie,

Qui estoit un foueur de chans.

De certain, ceulx sont bien meschans

Qui le prisent. La, voit son livre!
1240 Las! a paine seray delivre

De la douleur qui me tourmente.

Aler veul de loyal entente

Ou St. Fiacre prieray,

1244 Et son livre sy baiseray.

En son monstier vois droite voie.

**Biaulx seigneurs, Dieu vous ottroit joie!

Je vous veul dire verité:

1248 J'avoie le Saint despité

De siens trop vilainement,

Sy me escheï malement,

Mais tantost que m'en repenty,

1252 Alegence du mal senty.

Dieu soit loez!

**sT. PHARON

Biauls seigneurs, qui cez mos ouez,

Chantons, et ne soions pas muz,

1256 De cuer: Te Deum laudamus.

\section{Explicit}

1239. The second hemistich is presented in the MS as a stage direction. Since there are no four-syllable lines inside speeches elsewhere, since rubrics do not rhyme, and since the hemistich as edited fits rhyme and meter, it has been made a part of the line. 


\section{Appendix}

\section{Historical Notes}

709 r. Originally the brigant was a foot soldier wearing light armor known as a brigandine, described by Enlart, III, 279-83. On this, see Richard A. Newhall in Jean Birdsall's translation of the chronicle of Jean de Venette, p. 217 , n. 35. Froissart often uses the word in this sense. He tells us, for example (IV, 90 ff.), that brigants reinforced Spanish naval troops who were defeated by Edward III of England near Winchelsea in 1350, and (IV, 121) that they made up a part of the garrison of St.-Omer in 1351, bringing about the defeat of English attackers from Calais. After the Treaty of Brétigny in 1360 , remnants of several nationalities which had been in the military service of France and England, left footloose and without means of support, organized themselves into "compagnies" and committed the depredations which eventually gave them a bad reputation. On this, see Froissart, VI, $60 \mathrm{ff}$., and Molinier, IV, $74 \mathrm{ff}$. Godefroy's earliest example with the modern meaning of brigand (VIII, 375) is from the fifteenth century. However, the continuator of the chronicle of Richard Lescot, writing in 1390 of events of 1359, indicates that the change had already taken place when he refers (p. 138) to balistarios quingentos cum mille servientibus levis armature armatis qui tunc brigantes vocabantur. For further information concerning the activities of the "compagnies" in the fourteenth century, see Coville in Lavisse, Vol. IV, pt. 1, pp. 161-66, 181, 250-51; pt. 2, pp. 29, 89. Picardy seems to have been relatively free from these marauders, though Brie and Champagne, among other regions, were at times at their mercy. See Denifle, II, 477. The brigant in the VSF, who tries to steal a capon (though that is a thing which soldiers in all ages are likely to do), and who, in lines 789-90, is accused of living from thievery, may indeed be a member of one of the companies of marauders infesting France during the late fourteenth century. His statement that he had never before been in Picardy or in France, if we take the latter to be the entire country rather than merely the Ile-de-France, leads to the presumption that the author intended to present him either as a Burgundian in the service of his Duke, in whose territory St.-Omer was located, or else as one of the foreigners (Bretons, Germans, Spaniards, Dutch, etc.) who were with one of the armies stationed on the march of Calais.

713. This reference to St.-Omer is of no value for purposes of dating the VSF. Only forty miles from Calais, which was in English hands from 1347 until 1558, and in territory frequently disputed by various armies during the Hundred Years' War, the garrison of the town must often have been reinforced by the French and/or Burgundians. See note to line $709 \mathrm{r}$. above.

The reference seems to indicate that the brigant is within reasonable traveling distance of the town. If this assumption is correct, the farce takes place in a village of northern Picardy, which the author may have known personally (see above, p. 10, for Picard characteristics in his language). However, this is not necessarily true. So many sallies against the English and others either originated in or passed through St.-Omer during the second half of the fourteenth century, that its name would be familiar to any intelligent Frenchman of the time, such as our author. Moreover, the mention of St.-Magloire (see note to line 882), while by no means conclusive, seems to point rather to the region of Paris as the setting of the farce. The present editors have been unable to find any trace of a cult of St. Magloire, who was a Breton saint, or any locality named for him in the region of St.-Omer. Since there were brigands in Brie, it is entirely possible that the author intended his farce to take place there, perhaps in a village not far from the capital, like Marizy-Ste.-Geneviève, from which access to St.-Magloire in Paris would be possible. See p. 9 above, and note to 709 r. Perhaps the author knew that a chapel dedicated to St. Fiacre was at St.-Omer (see Ansart de Taupon, p. 85), and was therefore led to mention the town in his play, where geographical accuracy was not essential.

882. The abbey and church of St. Magloire, founded in the tenth century, were located at the end of the Rue Salle-au-Comte between Rue St. Denis and Rue Quincampoix. They were sold in 1790 by the Revolutionary government. See Dumolin and Outardel, p. xvi; LeRoux de Lincy, pp. 111 and 185. For further bibliography, see Chevalier, Vol. II, col. 2725. Before the opening of the Boulevard Sébastopol in 1857, there was a Rue St. Magloire ending near the church of St.-Leu-St.-Gilles at 92 Rue St. Denis. See Pessard, p. 1312. This reference does not necessarily serve to connect the play with Paris, though the presumption is strong. There may, of course, have been localities named for the Saint elsewhere. "Par Saint Magloire" was a frequent oath. See Roy, Etudes, p. cciv. 


\section{Glossary}

(Only those items are included which do not survive into Modern French or which do not appear with satisfactory definitions in readily accessible dictionaries of Old French.)

aing 431, ind. prés. 1 de aimer

ainsinques 523 , ainsi comme

alaine (a haulte a-) 731, à haute voix

argue 1078, ind. prés. 3 de arguer, tourmenter

asserray 342, fut. 1 de asseoir

aviser 169 , se raviser; avisiez 55 , imper., montrez; nous aviseron 276, nous nous guiderons

baris 922 , barils, estomacs (argot)

bouton (ne ... b-) 856, pas du tout

brache 928 , bras

breer 1181 , pousser des cris

capusse 778, capuce, tête (argot)

charra 592, fut. 3 de chëoir, tomber

chiere (a grant c-) 1071, volentiers

coffin 924, panier, estomac (argot)

cognoissance 211 , ceux qu'on connaît

contenance 52,115, 277, apparence

courrime 764 , maladie d'entrailles

clemené 360, manière d'agir

demener 13, 36, 195, mener

deporteray 930, fut. I de deporter, traiter bien

desdire 218,433 , nier

despiesse 971 , subj. prés. 1 de despiesser, dépecer

dessemaine 74 , pas cette semaine

dessirées 988 , déchirées

dissolu $61,341,376$, mauvais, infâme

doumache 1221, dommage, mal

eritage 422 , domaine

essoir 875 , hier soir

estraine 358, difficulté; a bonne e- 910 , librement; estre en pute $\mathrm{e}-358$, être maudit; souffrir en pute e- 1206, avoir beau souffir

estrier 734, s'efforcer

fent 377,379 , ind. prés 3 de fendre (fener), creuser la terre

ferray 769 , fut. 1 de ferir, frapper.

feroiez 807, 808, cond. 2 de faire

fiert 887 , ind. prés. 3 de ferir, frapper, convenir

fieuses 1148, femmes atteintes du fic, du mal de St. Fiacre (v. la note)

fois 1004 , ind. prés. 1 de faire (v. la note)

foueur 1237, laboureur

fourras 320, fut. 2 de foür, bêcher

fuet 932 , passé déf. 3 de estre

garde 1178, ind. prés. 1 de garder, essayer d'éviter

haussage 1174 , arrogance het 201, ind. prés. 3 de hair

hete 339 , ind. prés 3 de haitier, plaire

houel 748 , houe

lampas 765 , maladie de gueule des chevaux

latree 959, part. passé de latrer, battre avec une latte

lit (payer ton 1-) 831, être battu (argot)

loien 592, lien, piège

mardaille 1213, canaille (vulgaire)

matere 150 , disposition, caractère

merel 800,969 , mereau, coup (fig.)

mestrie 758 , domination; 838 , force

mon 1090, v. savoir

moult 871, 880, 905, espèce de vin; mous (pl.) 989

muaclement 140, comme un muet

nerfz 979, rudes, drus

nes 614 , pas même

parmy 919, au milieu

ouan 906, cette année

plessié 378, parc, clairière

poirée 760 , plante du genre bette

pois 760, petit pois

quarole 194, espèce de danse

quassé 945 , part. passé de quasser, casser

queurs 740 , ind. prés. 2 de courir

raviser 514 , connaittre

rois 546, sillons

saigne 813, imper. fam. de saigner, faire le signe de la croix

sanz 1132, ind. prés. 1 de santir

savoir mon se 1090, bien entendu que

semons 516, part. passé de semondre, inviter

sergent $783 \mathrm{r}$, etc., agent de police

soing (il n'a s-) 115, il ne veut pas

sondée 877 , part. passé de sonder, payer, endurer

soursse 855 , part. passé de sourdre, jaillir, résulter

tenement 445 , domaine, biens

tiegne 314, subj. prés. 3 de tenir; a moy tiegne, que ça soit empêché par moi

toudra 380 , fut. 3 de toudre, enlever tourtiex 932, cruel, bourreau (v. la note) traire 239, 1040, aller; 727, tirer trestant 516, tout de suite truis 1124, ind. prés. 1 de trouver usee (avoir a u-) 346, être habitué à vaille que vaille 432, quoi qu'il arrive vasisse 1123 , subj. impf. 1 de aler voison 617, subj.prés. 4 de aler 


\section{Bibliography}

(Anonymous works are listed alphabetically according to their titles)

Abrégé de la vie de Sainte Geneviève, patrone de Paris, Paris, 1646.

Adam le Bossu, Le Jeu de la feuillee, see Langlois.

Le leu de Robin et Marion, see Langlois.

Adamsspiel, Das, see Grass.

Ansart de Taupon, Histoire de Saint Fiacre et de son monastère, Paris, 1784.

Antiquitez et remarques de la chasse de Madame Saincte Geneviefve, Paris, 1625.

Bédier, Joseph, Les Légendes épiques, Paris, 1908-13.

Bédier, Joseph, et Hazard, Paul, Histoire de la littérature française illustrée, Paris, 1923-24.

Birdsall, Jean (transl.), The Chronicle of Jean de Venette, edited, with an introduction and notes, by Richard A. Newhall, New York, 1953.

Bollandists, Acta Sanctorum, Paris/Rome, 1868.

Bollandists, Bibliotheca hagiographica latina, Subsidia Hagiographica 6, Brussels, 1949 (reprint).

Burks, James F. (ed), La Resurrection Nostre Seigneur, unpublished dissertation, 1957, in the Indiana University Library; microfilm at University Microfilms, Ann Arbor, Mich.

Butler, Pierce, Legenda Aurea-Légende Dorée-Golden Legend, Baltimore, 1899.

Chevalier, Ulysse, Répertoire des sources historiques du moyen-âge. Topo-bibliographie, Montbéliard, 1894-1903.

Cohen, Gustave, Histoire de la mise en scène dans le théâtre religieux français du moyen-âge, Paris, 1926.

Le Livre de conduite du régisseur et le compte des dépenses pour le Mystère de la Passion joué à Mons en 1501, Paris, 1925.

"Le Théâtre à Paris à la fin du XIV e siècle," $R$, XXXVIII (1909), 587 ff.

Courtois d'Arras, Le, see Faral.

Craig, Barbara M. (ed.), L'Estoire de Griseldis, Lawrence, Kansas, 1954.

Creizenach, Wilhelm, Geschichte des neueren Dramas, 2nd. ed. rev., Halle, 1911.

Denifle, Henri, La Guerre de Cent Ans et la désolation des églises, monastères et hôpitaux en France, Paris, 1897-99.

Douët D'Arcq, L. (ed.), Choix de pièces inédites relatives au règne de Charles VI, Paris, SHF, 1864.

Dumolin, Maurice and Outardel, George, Les Églises de France. Paris et la Seine, Paris, 1936.

Dumolinet, Claude, Histoire de Sainte Geneviève et de son Eglise Royale et Apostolique, Bibl. Ste.-Gen. MS. 610.

Inventaire des principaux manuscrits de la bibliothèque de l'abbaye de Sainte Geneviève, Bibl. Ste.-Gen. MS. 965.

Enlart, Camille, Manuel d'archéologie fraņ̧aise, Paris, 1916.

Estoire de Griseldis, $L^{\prime}$, see Craig.

Faral, Edmond (ed.), Le Courtois d'Arras, 2e. éd. rev., CFMA, 3, Paris, 1922.

Foulet, Lucien, Petite syntaxe de l'ancien français, CFMA, 21, Paris, 1930.

Fournier, Edouard, Le Théâtre français avant la Renaissance, Paris, n.d. [1872].

Frank, Grace, Medieval French Drama, Oxford, 1954.

Froissart, Jean, Chroniques, Paris, SHF, 1869-1931. Vols 1-8 ed. Siméon Luce; vols 9-12, ed. Gaston Raynaud.

Garçon et l'aveugle, Le, see Roques.

Godefroy, Frédéric, Dictionnaire de l'ancienne langue française, Paris, 1881-98. 


\section{BIBLIOGRAPHY}

Graesse, Johann, Legenda aurea, Vratislavie, 1890.

Grass, Karl (ed.), Das Adamsspiel, dritte verb. Auflage, Halle, 1928.

Groeber, Gustav, Geschichte der mittelfranzösischen Literatur, bearb. von S. Hofer, Berlin, 1933-37.

Guénot, G., Sainte Geneviève, sa confrérie et ses fêtes, Paris, 1854.

Hardy, Thomas Duffus, Descriptive Catalogue of Materials Relating to the History of Great Britain and Ireland, Rolls Series, London, 1862.

Harvey, Howard G., The Theatre of the Basoche, Cambridge (Mass.), 1941.

Holbrook, R. T. (ed.), Maistre Pierre Pathelin, 2e éd. rev., CFMA, 35, Paris, 1924.

Jean Bodel d'Arras, Le Jeu de St. Nicolas, see Jeanroy.

Jean de Venette, see Birdsall.

Jeanroy, Alfred (ed.), Jean Bodel d'Arras, Le Jeu de St. Nicolas, CFMA, 48, Paris, 1925.

Knowles, Christine, "Jean de Vignay, un traducteur du XIIIe siècle," $R$, LXXV (1954), 353 ff.

Kohler, Charles, Catalogue des manuscrits de la Bibliothèque Sainte Geneviève, Paris, 1893-96.

Kraemer, Erik V., Les Maladies désignées par le nom d'un saint, Copenhagen/Helsingfors, 1950.

Langlois, Ernest (ed.), Adam le Bossu, Le leu de la feuillee, 2e éd. rev., CFMA, 6, Paris, 1923.

Adam le Bossu, Le Jeu de Robin et Marion, CFMA, 36, Paris, 1924.

Lanson, Gustave, Histoire de la littérature française, Paris, 1912.

LaVallière, duc de, Bibliothèque du théâtre françois, Dresden, 1768.

Lavisse, Ernest, Histoire de France, Paris, 1902.

Lecotté, Roger, Recherches sur les cultes populaires dans l'actuel diocèse de Meaux, Paris, 1954.

LeMasson, J.-B., Le Calendrier des confréries de Paris, ed. V. Dufour, Paris, 1875.

Lemoine, Jean (ed.), Chronique de Richard Lescot, Paris, SHF, 1896.

LeRoux de Lincy, Paris et ses historiens au XIVe et XVe siècles, Paris, 1867.

Lescot, Richard, see Lemoine.

Loomis, Laura H., "Secular Dramatics in the Royal Palace, Paris, 1378, 1379, and Chaucer's

Tragetoures," Speculum, XXXIII (1958), 242-55.

Maistre Pierre Pathelin, see Holbrook.

Miracles de Nostre Dame, Les, see Paris.

Miracles de Sainte Geneviève, Les, see Sennewaldt.

Molinier, Auguste, Sources de l'histoire de France, Paris, 1901-06.

Mystères inédits du quinzième siècle, ed. Achille Jubinal, Paris, 1837.

Nativité, La, and Le Geu des trois roys, see Whittredge.

Newhall, Richard A., see Birdsall.

Paetow, Louis J., Guide to the Study of Medieval History, New York, 1931.

Paris, Gaston, et Robert, U. (eds.), Les Miracles de Nostre Dame, Paris, SATF, 1876-93.

Penn, Dorothy, The Staging of the "Miracles de Nostre Dame par personnages," New York, 1933.

Pessard, Gustave, Nouveau dictionnaire historique de Paris, Paris, 1904.

Petit de Julleville, L., Les Mystères, Paris, 1880.

$$
\text { Répertoire du théâtre comique en France au moyen-âge, Paris, } 1886 .
$$

Poewe, Julius, Sprache und Verskunst der Mystères inédits du XVe siècle, diss., Halle, 1900.

Porter, M. E. and Baltzell, J. H., "The Medieval French Lives of Saint Fiacre," Modern Language Quarterly, XVII (1956), 21-27.

Resurrection Nostre Seigneur, La, see Burks.

Roques, Mario (ed.), Le Garçon et l'aveugle, 2e éd. rev., CFMA, 5, Paris, 1921.

Roy, Emile, Le Mystère de la Passion en France, Dijon/Paris, 1903.

Etudes sur le théâtre français du XIVe siècle, Paris, 1902.

Sennewaldt, Clotilde (ed.). Les "Miracles de Sainte Geneviève," Frankfurt, Frankfurter Quellen und Forschungen, 1937. 


\section{BIBLIOGRAPHY}

Sneyders de Vogel, K., Syntaxe historique du français, Groningen/The Hague, 1919.

Thomas, Antoine, "Le théâtre à Paris et aux environs à la fin du XIVe siècle," $R, \mathrm{XXI}$ (1892), 609-10.

Voretzsch, Karl, Introduction to the Study of Old French Literature, transl. F. M. DuMont, New York, 1931.

Wacker, Gertrud, Über das Verhältnis von Dialekt und Schriftsprache im Alttranzösischen, Halle, 1916.

Walton, Thomas, "Staging Le leu de la feuillee," Modern Language Review, XXXVI (1941), 344-50.

Whittredge, Ruth (ed.), La Nativité et le Geu des trois roys, Bryn Mawr, 1944.

Wilmotte, Maurice, Etudes critiques sur la tradition littéraire en France, Paris, 1909.

Wright, Jean G., Study of the Themes of the Resurrection in the Medieval French Drama, Bryn Mawr, 1935.

Young, Karl, The Drame of the Medieval Church, Oxford, 1933. 


\section{Volume V}

Number 1. Public Intelligence. A Study of the Attitudes and Opinions of Voters, by Seba Eldridge. June, 1935. One hundred and one pages. One dollar; cloth, one dollar and fifty cents.

Number 2. Relationship of the Latin Facetus Literature to the Medieval English Courtesy Poems, by Sister Mary Theresa Brentano, O.S.B. June, 1935. One hundred and thirty-three pages. One dollar.

Number 3. The London Journal and its Authors, 1720-1723, by Charles Bechdolt Realey. December, 1935. Thirty-eight pages. Fifty cents.

Number 4. The Relationship of the Perlesvaus and the Queste del Saint Graal, by J. Neale Carman. July, 1936. Ninety pages. One dollar.

\section{Volume VI}

Number 1. The Kansas Labor Market with Special Reference to Unemployment Compensation, by Domenico Gagliardo. February, 1937. Seventy-one pages. One dollar.

Number 2. El Secreto a Vozes, by Pedro Calderon de la Barca, edited by José M. de Osma. April, 1938. One hundred and thirty-eight pages. One dollar.

Number 3. A German Conscript with Napoleon, edited and translated by Otto Springer. November, 1938. Two hundred and thirty-one pages. One dollar and fifty cents.

Number 4, Studies in English, by Members of the English Department at the University of Kansas. August, 1940. One hundred and eight pages. One dollar.

Number 25. The Life and Works of George Turbervile, by John Erskine Hankins. 1940. Ninety-eight pages. One dollar.

Number 26. Medieval Latin Studies: Their Nature and Possibilities, by L. R. Lind. 1941. Forty-eight pages. Fifty cents.

Number 27. Tennyson in Egypt: A Study of the Imagery in His Earlier Work, by W.D. Paden. 1942. One hundred and seventy-eight pages. One dollar and fifty cents.

Number 28. El Verdadero Dios Pan, by Pedro Calderon de la Barca, edited by José M. de Osma. 1949. One hundred and forty-nine pages. Two dollars and fifty cents.

Number 29. Studies in Honor of Albert Morey Sturtevant. 1952. One hundred and sixty-nine pages. Two dollars and fifty cents.

Number 30. Persecution of the Jews in the Roman Empire (300-438), by James E. Seaver. 1952. One hundred and one pages. Two dollars.

Number 31. L'Estoire de Griseldis, edited by Barbara Craig. Eighty-four pages. Two dollars and fifty cents.

Number 32. Cooper's Theory of Fiction, by Arvid Shulenberger. One hundred and five pages. Two dollars and fifty cents.

Number 33. La Vie Monseigneur Saint Fiacre, edited by James F. Burks, Barbara M. Craig, and M. E. Porter. Forty-three pages. Two dollars. 